\title{
Portal e-Brosur Berbasis Modern Advertising Methods Untuk Efektifitas Periklanan
}

\author{
Erlangga Erlangga, Alfan Furqon \\ Program Studi Sistem Informasi \\ Fakultas Ilmu Komputer, Universitas Bandar Lampung \\ Jl. Zainal Abidin Pagar Alam No. 26 Labuhan Ratu Bandar Lampung 35142 \\ Email : erlanga@y7mail.com, alfanfurqon@gmail.com
}

\begin{abstract}
Brochure printing is one of the marketing strategies for the company for marketing its products. Emarketing, advertising services are now getting the attention of the public since the aspects of information becomes important in business. Effective advertising activities deemed capable of affecting the Internet user community.

By using modern advertising methods or modern advertising methods are expected E-brochures can be a new innovation to the world of e-marketing. Using this method there is Profit and loss of both marketers and consumers in particular. Advantages era could now access modern advertising we find easily on the internet so marketers can easily advertise their products but some rogue marketers who make fraudulent internet as a place to advertise that do not conform to the norms of moral, cultural and religious, and it can annoy even harm consumers or internet users.

Based on the above background, the authors are interested in conducting research on building systems-based Portal E-brochure Modern Advertising Methods For advertising effectiveness of e-marketing and pour in the form of a research proposal titled "Portal-Based E-Brochure Modern Advertising Methods for Effectiveness Advertising ".
\end{abstract}

Keywords: CMS, E-Brosur

\section{PENDAHULUAN}

\subsection{Latar Belakang}

Percetakan brosur merupakan salah satu strategi marketing bagi perusahaan untuk pemasaran produknya. Layanan periklanan emarketing sekarang mendapatkan perhatian dari masyarakat semenjak aspek-aspek informasi menjadi penting dalam bisnis. Kegiatan periklanan yang efektif dipandang mampu mempengaruhi masyarakat pengguna internet. Periklanan e-marketing yang efektif akan mengubah pengetahuan publik mengenai ketersediaan dan karaktersistik beberapa produk. Elastisitas permintaan produk akan sangat dipengaruhi aktivitas periklanan, belakangan secara intensif dipromosikan melalui media massa dalam bentuk iklan dengan teknik modern.

Meningkatnya gobalisasi ekonomi dunia membuka kesempatan pasar yang luas bagi para perusahaan. Hal ini tentu menimbulkan persaingan bagi para pelaku pasar agar mencapai kinerja yang lebih baik (Paul, 1997: p.27). Kaburnya batas-batas negara dalam konteks perdagangan dunia, membawa konsekuensi persaingan yang semakin meluas dan bergesenya kekuasaan produsen ke tangan konsumen (Simatupang, 1996: p.46).

Manajer yang inovatif perlu mencari cara dan menciptakan bisnis yang unik agar lebih efektif baik di lokal, regional maupun global sehingga mereka memperluas pendapatan mereka, menekan biaya mereka, serta meningkatkan ke untungan mereka (Paul,1996: p27; Talha et al.).

Pada awalnya menggunakan halaman halaman statis berformat HTML yang bisa diakses oleh pengguna internet. Itulah awal dari website yang menjadi semacam 'broshure online' dan juga bisa jadi pemasaran brosur pada dunia pendidikan.

E-brosur merupakan salah satu cara pemasaran produk, jasa, dan lain - lain dengan menggunakan media elekronik. Dimana elektronik yang di maksud disini adalah media internet ataupun online pada perkembangan dunia online marketing tidak hanya menggunakan media website. Namun juga email dan aplikasi aplikasi lain yang berjalan $\mathrm{di}$ atas protocol internet sebagai bagian dari kegiatan marketing dengan menggunakan media internet. E-brosur menjadi kajian yang menarik bagi para marketer khususnya dan usaha umumnya. Dengan 
mengunakan metode periklanan modern atau modern advertising methods diharapkan E-brosur bisa menjadi inovasi baru untuk dunia $e$ marketing.

Mengunakan metode ini ada keuntungan dan kerugian baik marketer khususnya dan konsumen. Keuntungan dijaman sekarang mengakses periklanan modern bisa kita jumpai dengan mudah di internet sehingga marketer bisa mudah memasang iklan produknya namun ada juga marketer nakal yang menjadikan internet sebagai tempat penipuan memasang iklan yang tidak sesuai dengan norma moral, cultural dan agama dan itu bisa mengganggu bahkan merugikan konsumen atau pengguna internet.

Berdasarkan uraian latar belakang diatas, maka penulis tertarik untuk mengadakan penelitian tentang membangun sistem portal ebrosur berbasis Modern Advertising Methods untuk efektivitas periklanan dan menuangkan dalam bentuk proposal penelitian dengan judul "Portal E-Brosur Berbasis Modern Advertising Methods Untuk Efektivtas Periklanan".

\subsection{Identifikasi Masalah}

Adapun identifikasi masalah yang ada pada penelitian ini adalah :

a. Dengan menggunakan brosur biasa dibutuhkan biaya yang cukup tinggi dalam membuatnya

b. Dengan menggunakan brosur biasa banyak penerima informasi yang tidak membutuhkan informasi tersebut.

c. Penyebaran brosur dan iklan cetak kurang efektif.

\subsection{Batasan Masalah}

Adapun yang menjadi batasan masalah penelitian ini adalah: Membangun sistem Portal E-Brosur berbasis Modern Advertising Methods untuk efektivitas periklanan.

\subsection{Rumusan Masalah}

Adapun masalah yang akan diangkat oleh penulis adalah "Bagaimana membangun sistem Portal E-Brosur Berbasis Modern Advertising Methods untuk efektivitas Periklanan?"

\subsection{Tujuan Penulisan}

Tujuan penulisan ilmiah ini adalah:

a. Mengurangi biaya pemasaran dengan membuat aplikasi portal e-brosur yang mengurangi biaya brosur cetak. b. Membuat aplikasi portal e-brosur yang akan membantu pencari iklan dan menemukan iklan yang akan di cari, sehingga lebih tepat sasaran

c. Mengukur tingkat keefektivitasan e-brosur.

\subsection{Manfaat Penulisan}

Manfaat dari penulisan ilmiah ini adalah sebagai:

a. Memberikan manfaat teoritis sehingga menambah khasanah baru bagi ilmu pengetahuan maupun peneliti selanjutnya yang ingin mengembangkan lebih lanjut penelitian.

b. Menambah pengetahuan, wawasan dalam ilmu periklanan berbasis web dan juga pengalaman sehingga dapat menjadi tenaga kerja yang berguna dan siap menghadapi tantangan dunia kerja sesungguhnya.

c. Diharapkan sistem portal e-brosur dapat diterapkan oleh semua penyedia layanan iklan. Dapat memberikan informasi tentang e-brosur dunia pendidikan maupun perusahaan.

\subsection{Tinjuan pustaka}

Tinjauan pustaka diambil dari beberapa buku, jurnal dan artikel yang berhubungan dengan penelitian ini adalah sebagai berikut:

a. Penelitian yang dilakukan oleh Bertha (Staff Pengajar Fakultas Ekonomi Universitas Surabaya), bulan November tahun 2006, dengan judul "Internet Marketing: Konsep Dan Persoalan Baru Dunia Pemasaran”, memaparkan internet marketing sebagai paradigma baru pemasaran. Perubahan paradigma tersebut berpengaruh terhadap model bisnis untuk penciptaan nilai pelanggan (customer value creation), cara merebut dan mempertahankan nilai pelanggan di web (analisis 4C dan 4P) serta cara pemasaran lewat internet.

b. Penelitian yang dilakukan oleh Piranti Warta, bulan April tahun 2008 dengan judul "Korelasi Antara Kualitas Portal DetikPortal Dengan Kepuasan Member PT AMS", Artikel bertujaun untuk mengetahui hubungan antara kualitas detikportal dengan kepuasan menber pt ams. Metode penelitian yang digunakan metode survei, yaitu teknik korelasional dengan metode pengumpulan data mengunakan kuesioner.

c. Penelitian yang dilakukan oleh Ivan Bulut and bojana Radenkovic sosic (candidat Doktor Megatrend Universty, Belgrade), tahun 2011, dengan judul "Kegiatan 
tanggung jawab sosial sebuah metode iklan modern?". Penelitian ini membahas tentang penggunaan Bisnis yang bertanggung jawab sosial adalah sebuah kosep bisnis modern yang telah diadaptasi banyak perusahaan, yang berusaha dengan berbagai cara untuk berkonstribusi pada pemecahan masalah sosial saat ini dan dengan demikian, membangun sikap publik yang positif dan citra pelaku pasar bertanggung jawab secara social. Presentasi kegiatan perusahaan bertanggung jawab sosial dapat dilakukan dengan cara berbeda oleh iklan, menginformasi kelompok yang berkepentingan iklan sosial yang bertanggung jawab, atau dengan menyelenggarakan kegiatan tanggung jawab sosial. Makalah ini membahas ada berbagai metode komunikasi dengan grup publik sasaran, iklan mereka dan hasil studi terbaru pada sikap konsumen mengenai kegiatan tersebut.

\subsection{Landasan teori}

\subsubsection{Definisi Metodologi Penelitian}

Penelitian didefinisikan oleh banyak penulis sebagai suatu proses yang sistematik. $M c$ Millan dan Schumacher (1989) dalam Wiersma (1991: p7), "mendefinisikan penelitian sebagai "suatu proses sistematik pengumpulan dan penganalisisan informasi (data) untuk berbagai tujuan". Sementara Kerlinger (1990: p17) "mendefinisikan penelitian ilmiah sebagai "penyelidikan sistematik, terkontrol, empiris, dan kritis tentang fenomena social yang dibimbing oleh teori dan hepotesis tentang dugaan yang berhubungan dengan fenomena tersebut". Secara umum metode penelitian diartikan sebagai cara ilmiah untuk mendapatkan data dengan tujuan dan kegunaan tertentu.

\subsubsection{Definisi Portal}

Portal menurut Dictionary of Computing (2002: p582) adalah "website provider link to information and another website" yang berarti website yang menyediakan link tentang informasi dan website lain.

\subsubsection{Modern Advertising Methods}

Modern Advertising Methods (Metode periklanan modern) adalah suatu cara untuk melakukan kegiatan menyebarluaskan berita (informasi) kepada pasar (masyarakat/konsumen) untuk mendapatkan tujuan dan kegunaan tertentu selain itu juga berfungsi untuk membujuk atau mempengaruhi, menciptakan kesan, memuaskan keinginan dengan berbagai cara sebagai alat komunikasi seperti media cetak, elektronik atau internet, brosur, dan billboard/baliho/spanduk.

Brosur adalah salah satu metode periklanan modern dan brosur sebagai salah satu produk advertising yang sering digunakan contoh oleh rumah sakit. Brosur yang memuat profil rumah sakit lengkap dengan fasilitas yang dimiliki, serta jam praktek dokter. Brosur disediakan dan didistribusikan bagi konsumen dan calon konsumen yang datang ke rumah sakit.

Periklanan adalah kegiatan

menyebarluaskan berita (informasi) kepada pasar (masyarakat/konsumen). Selain itu iklan juga berfungsi untuk membujuk atau mempengaruhi, menciptakan kesan, memuaskan keinginan dan sebagai alat komunikasi (Kotler dan Gary Armstrong 2008). Periklanan meliputi: media cetak dan elektronik, brosur, dan billboard/baliho/spanduk.

Salah satu media elektronik adalah radio. Siaran radio adalah médium yang menyerap 96 persen dari semua orang yang berusia 12 tahun ke atas. Angka rata-rata nasional sebanyak 2,8 jam mendengarkan radio setiap hari.

Menurut Kotler dan Keller. Periklanan / advertising meliputi yaitu:

a. Media cetak dan elektronik

Media cetak berupa koran / majalah, sedangkan media elektronik berupa CD, VCD, internet / website, siaran radio dan televisi (TV). Biaya termahal adalah televisi (TV).

b. Brosur

Brosur sebagai salah satu produk advertising yang digunakan contoh oleh rumah sakit. Brosur yang memuat profil rumah sakit lengkap dengan fasilitas yang dimiliki, serta jam praktek dokter. Brosur disediakan dan didistribusikan bagi konsumen dan calon konsumen yang datang ke rumah sakit.

c. Billboard

Billboard /Baliho /spanduk digunakan juga oleh pihak manajemen perusahaan sebagai alat promosi didalam mengkomunikasikan kepada konsumen / calon konsumen tentang keberadaannya, namun hanya dipasang didepan kantor masing-masing dan tempat-tempat strategis.

\subsubsection{Keuntungan dan Kerugian}

Dalam mengunakan Modern Advertising Methods ini, dibeberapa bidang terdapat 
keuntungan dan kerugian, misalnya bertentangan dengan norma - norma yang berlaku. Adapun bidang-bidang tersebut sebagai berikut:

a. Bidang politik

Pernyataan politik murahan tertentu, yang meskipun disadari sebagai politik pembohongan massa, tetapi tetap saja merasuk ke dalam kesadaran masyarakat karena iklan-iklan tersebut ditayangkan pada prime time di televise-televisi atau radio-radio, atau dipajang di jalan- jalan protocol. Lebih mengerikan lagi keadaannya jika media-media massa dikontrol secara ketat dengan kewajiban mematuhi aturan-aturan tertentu yang secara jelas hanya menguntungkan rezim penguasa, atau juga kewajiban menayangkan secara serentak acara-acara atau iklan-iklan kenegaraan tertentu.

b. Bidang Kultural

Secara ideal harus dikatakan bahwa iklan semestinya dikemas sebegitu rupa supaya tidak hanya bernilai secara moral, tetapi juga intelektual dan estetis. Selain itu, para pemasang iklan juga mesti mempertimbangkan kebudayaan dari masyarakat yang menjadi "sasaran" iklan. Prinsip umum yang dianut adalah bahwa masyarakat harus selalu diuntungkan secara kultural. Hal ini hanya bisa terwujud kalau isi iklan bukan merupakan cerminan dari kehidupan glamor kelompok kecil masyarakat kaya atau pun masyarakat dunia pertama yang wajib diimitasi secara niscaya oleh mayoritas masyarakat miskin atau pun masyarakat dunia ketiga, tetapi merupakan cerminan dan dinamisme kehidupan masyarakat miskin itu sendiri, karena iklan menginformasikan barang dan jasa yang sungguhsungguh mereka butuhkan,dan itu berarti sesuai dengan stadar hidup mereka.

Prinsip yang secara etis dipegang teguhadalah bahwa iklan tidak harus pertamatama menciptakan kebutuhan-kebutuhan baru, atau mengekspos pola kehidupan baru yang malah mengasingkan masyarakat dari kebudayaannya sendiri. Dalam kenyataannya, iklan lebih sering menampilkan kebudayaan hidup masyarakat yang lebih suka menonjolkan kompetisi di segala bidang kehidupan seraya membuang jauhjauhrasa solidaritas antarsesama. Iklan juga seringkali meremehkan unsur-unsur edukatif, standar moral serta seni yang tinggi. Bahkan boleh dikatakan bahwa sebagaian besar iklan menampilkan warna dominasi kaum lelaki atas kaum perempuan.

c. Bidang Moral dan Agama
Ajaran-ajaran moral dan agama juga sering kali disampaikan lewat iklan. Ajaran-ajaran moral dan agama tersebut kepatuhan kepada kehendak Yang Ilahi, toleransi, belas kasihan, pelayanan dan contah kasih kepada sesama yang lebih membutuhkan pertolongan, pesan-pesan mengenai kesehatan dan pendidikan, dan lain-lain bertujuan untuk memotivasi masyarakat kearah kehidupan yang baik dan membahagiakan. Masalah muncul ketika iklan bertentangan dengan ajaran-ajaran moral dan agama.

Bagi kaum moralis maupun agamawan, hal yang secara jelas bertentangan dengan arahan moral dan agama adalah pornografi dalam iklan. menurut Niklos Tomko, "Eastern Europe: The Media in Transition", dalam Concillium, SCM Press, London,1993/6. (Hlm 47-49) mengatakan pornografi yang diekspos itu merupakan sisi gelap dari kodrat manusia kaum agamawan menyebut sisi ini sebagai "gudang dosa" dan pelecehan terhadap martabat manusia. Selain itu, iklan yang diwarnai oleh kekerasan juga bertentangan dengan ajaran moral serta agama, dengan alasan yang kurang lebih sama seperti pada pornografi. Beberapa prinsip moral yang Perlu dalam Iklan Terdapat paling kurang 3 prinsip moral yang bisa dikemukakan di sini sehubungan dengan penggagasan mengenai etika dalam iklan. Ketiga hal itu adalah:

a. Masalah kejujuran dalam iklan,

b. Masalah martabat manusia sebagai pribadi, dan

c. Tanggung jawab sosialyang mesti diemban oleh iklan.

Ketiga prinsip moral yang juga digarisbawahi oleh dokumen yang dikeluarkan dewan kepausan bidang komunikasi sosial untuk masalah etika dalam iklan ini kemudian akan didialogkan dengan pandangan Thomas $M$. Gerrett, SJ yang secara khusus menggagas prinsip-prinsip etika dalam mempengaruhi massa (bagi iklan) dan prinsip-prinsipetis konsumsi (bagi konsumen).

Dengan demikian, uraian berikut ini akan merupakan "perkawinan" antara kedua pemikiran tersebut:

1. Prinsip Kejujuran dalam Iklan

Prinsip ini berhubungan dengan kenyataan bahwa bahasa penyimbol iklan sering kali dilebihlebihkan, sehingga bukannya menyajikan informasi mengenai persediaan barang dan jasa yang dibutuhkan oleh konsumen, tetapi mempengaruhi bahkan menciptakan 
kebutuhan baru. Maka yang ditekankan di sini adalah bahwa isi iklan yang dikomunikasikan haruslah sungguh-sungguh menyatakan realitas sebenarnya dari produksi barang dan jasa. Sementarayang dihindari di sini, sebagai konsekuensi logis, adalah upaya manipulasi dengan motif apa pun juga.Di Amerika Serikat, misalnya, dalam pembuatan iklan hal-hal berikut ini dilarang:

a Pesan yang tidak jujur atau yang sifatnya menyesatkan karena melebih-lebihkan kenyataanapa adanya dari barang dan jasa yang diiklankan.

b Menafsirkan secara salah isi (content) produksi sebuah barang dan jasa, entah itu dilakukan oleh produsen sendiri (the advertisers) atau oleh pihak editor maupun fotografer.

c Pernyataan-pernyataan atau pesan-pesan yang bertentangan dengan tatakrama masyarakat.

d Pernyataan-pernyataan yang bermaksud melecehkan perusahaan lain lewat propaganda bahwa barang dan jasa yang dihasilkan perusahaan lain itu tidak bermutu. (5) Klaim-klaim harga yang menyesatkan,

e Pernyataan- pernyataan atau pesan-pesan yang mengaburkan arti yang sebenarnya dan juga tidak aplikabel, tetapi kemudian diklaim sebagai yang didukung oleh pendapat para ahli atau otoritas ilmiah tertentu.

f Menegaskan kualitas barang dan jasa lewat kesaksian dari konsumen tertentu yang tidak kompeten sehingga pendapatnya tidak mencerminkan pilihan yang sejati dan bertanggung jawab mengenai pemakaian barang dan jasa tertentu.

g Iklan-iklan yang lebih mementingkan unsur sugesti, dalam arti menonjolkan dimensi-dimensi emosional, dorongandorongan bawah-sadar dan seks, di mana lewat hal-hal ini dimensi rasionalitas manusia tidak mendapat tempat yang wajar.

Dari deskripsi ini sebenarnya ditekankan bahwa iklan sesungguhnya adalah sebuah media informasi mengenai kelangkaan barang dan jasa yang dibutuhkan konsumen, dengan catatan bahwa tanpa dipengaruhi oleh aneka iklan yang canggih pun konsumen tetap mencari dan mendapatkan barang dan jasa yang ia butuhkan karena itu merupakan kebutuhan-kebutuhan (Thomas M. Garrett, SJ., 1961).

Dasar masalahnya tentu saja akan menjadi lain jika peran iklan bergeser menjadi upaya penumpukan profit setinggi mungkin, sehingga yang tampak adalah iklan-iklan yang bersifat propaganda.Hal terakhir ini yang justru ditolak secara etis, karena bukan saja melecehkan kebebasan manusia dalam memilih barang dan jasa yang ia perlukan, tetapi juga mencoreng peran mulia dari iklan itu sendiri selaku penyaji informasi yang jujur.

2. Prinsip Martabat Manusia sebagai Pribadi Bahwa iklan semestinya menghormati martabat manusia sebagai pribadi semakin ditegaskan dewasa ini sebagai semacam tuntutn imperatif (imperative requirement Iklan semestinya menghormati hak dan tanggung jawab setiap orang dalam memilih secara bertanggung jawab barang dan jasa yang ia butuhkan. Ini berhubungan dengan dimensi kebebasan yang justru menjadi salah satu sifat hakiki dari martabat manusia sebagai pribadi.

Maka berhadapan dengan iklan yang dikemas secanggih apa pun, setiap orang seharusnya bisa dengan bebas dan bertanggung jawab memilih untuk memenuhi kebutuhannya atau tidak. Yang banyak kali terjadi adalah manusia seakan-akan dideterminir untuk memilih barang dan jasa yang diiklankan, hal yang membuat manusia jatuh ke dalam sebuah keniscayaan pilihan. Keadaan ini bisa terjadi karena kebanyakan iklan dewasa ini dikemas sebegitu rupa sehingga menyaksikan, mendengar atau membacanya segera membangkitkan "nafsu" untuk memiliki barang dan jasa yang ditawarkan (lust), kebanggaan bahwa memiliki barang dan jasa tertentu menentukan status sosial dalam masyarkat, dll. Jika ini terjadi maka, menurut Thomas M. Garreth, SJ, iklan sesungguhnya melupakan satu hal yang dalam etika iklan sendiri telah diterima: "Kewajiban bertindak rasional" dan kewajiban "membantu orang lain untuk bertindak yang sama." Tentang hal ini Garreth menulis: "Kita semua berkewajiban untuk bertindak berdasarkan refleksi dan pertimbanganpertimbangan rasional."

Tetapi sejauh sebagai manusia selalu saja terjadi bahwa kita bertindak secara irasional. Inilah keterbatasan ruang dan waktu kita yang membuat hanya sebagian kecil dari kita yang biasa bertindak rasional dan manusiawi. Demikianlah dengan meminta kita bertindak 
secara rasional para etikawan mengkualifikasi kewajiban-kewajiban tertentu yang mesti kita penuhi. Dengan bertindak rasional terhadap kewajiban-kewajiban tersebut kita memperlihatkan pula tanggung jawab selalu pribadi. Pada titik ini pula kita dievaluasi secara moral.

Dalam konteks inilah, baik Gereja Katolik, maupun Thomas M. Garreth, SJ sendiri mengecam habis-habisan iklan yang semata-mata mementingkan unsure irasional dan sugestif sebagai yang melawan cinta kasih kepada sesama, karena iklan-iklan tipe ini melecehkan manusia sebagai animale rationale yang semestinya selalu bertindak rasionaldalam setiap tindakannya, karena hanya dengan demikian ia bisa dengan bebas dan bertanggung jawab menentukan pilihan-pilihannya. Lebih mengerikan lagi adalah bahwa iklan seringkali merugikan anak-anak yang tingkat kesadaran serta otonomi moralnya masih sangat terbatas, atau juga masyarakat miskin yang pada umumnya belum membebaskan diri (Thomas M. Garrett, SJ., 1961: p37-94).

\subsubsection{Periklanan (Advertising)}

Menurut F.Dzefkins advertising adalah salah satu bentuk dimana pelaku pasar berkomunikasi dengan target pasar mereka. yang berwenang british institute untuk pemasaran iklan didefinisikan, sebagai proses mendefinisikan menguntungkan manajemen, memprediksi, dan memuaskan kebutuhan pelanggan.

(F.Dzefkins, Oglasavanje, Clio, Beograd, 2003,p.10.)

\subsubsection{Sekilas tentang iklan (Advertising)}

Iklan adalah suatu pesan yang dikemas sedemikian rupa sehingga mampu mempengaruhi dan mengubah persepsi banyak orang dalam hal ini khalayak sebagai konsumen iklan. Disiplin ilmu yang terlibat didalam iklan yaitu, desain adalah proses penciptaan sebuah bentuk, dalam hal ini iklan agar terlihat menarik dan mudah dimengerti oleh konsumen penerima iklan. Kemudian selanjutnya adalah komunikasi yaitu bahasa atau apapun yang digunakan oleh produsen pembuat iklan agar iklan yang dibuat dapat dengan mudah diterima oleh konsumen dengan memperhatikan segmentasi, faktor demografis dan faktor lainnya yang dapat mempengaruhi konsumen di waktu konsumen menafsirkan dan mengkonsumsi iklan.
Selanjutnya adalah marketing ini maksudnya adalah pemasaran, bagaimana sebuah iklan dapat berhasil diterima oleh konsumen tergantung kepada strategi market atau pasar yang ditetapkan dan dipilih oleh produsen sebagai pembuat iklan. Dan yang terakhir adalah media, ini sangatlah berperan besar didalam penentuan keberhasilan sebuah iklan, selain dengan market yang benar dan baik pemilihan media juga dapat mempengaruhi keberhasilan iklan.

Selain itu iklan juga mempunyai fungsi fungsi didalam keberadaannya. Fungsi iklan yang pertama adalah fungsi ekonomis yaitu iklan yang diciptakan dan dipasarkan kepada konsumen biasanya bersifat komersil atau iklan yang sifatnya menjual, baik itu sebuah produk atau apapun. Yang kedua yaitu iklan yang mempunyai fungsi komunikasi maksudnya yaitu iklan yang ada hanya bersifat memberitahukan tanpa ada unsur komersil didalamnya, iklan seperti ini biasanya berbentuk iklan layanan masyarakat dan hanya bersifat pemberitahuan. Jadi pada dasarnya iklan yang bersifat sosial ini selalu bertujuan sebagai layanan masyarakat untuk menumbuhkan kesadaran dan ajakan atau informasi yang diterima agar dilaksanakan atau dilakukan oleh konsumen penerima iklan.

\subsubsection{Sejarah iklan (Advertising)}

Sebelum Gutenberg menemukan sistem percetakan pada tahun 1450, iklan sudah dikenal manusia dalam bentuk pesan berantai. Pesan berantai itu disampaikan untuk membantu kelancaran jual beli masyarakat yang mayoitas kala itu masih belum mengenal huruf, dengan cara barter. Dunia pemasaran menyebut pesan berantai itu sebagai the word of the mouth.

$$
\text { Demikianlah iklan pertama kali }
$$
diperkenalkan melalui pengumumanpengumuman yang disampaikan secara lisan, artinya dilaksanakan melalui komunikasi verbal. Karena disampaikan secara lisan, maka daya jangkauannya sempit. Namun untuk ukuran ketika itu, iklan yang demikian sudah dianggap cukup efektif. Selanjutnya iklan mengalami perkembangan menjadi bentuk relief yang diukir pada dinding - dinding. Pada zaman Caesar banyak toko di kota-kota besar yang telah mulai memakai tanda - tanda dan simbol atau papan nama. Itulah media utama dalam beriklan yang digunakan masyarakat Romawi pada masa itu. Melalui iklan orang dapat mempelajari sejarah peradaban manusia pada suatu masa. Pada awal abad 16 dan 17 yang banyak ditampilkan adalah 
iklan tentang budak belian, kuda (pada masa itu belum ada mobil), serta produk - produk baru seperti buku dan obat-obatan ketika itu menunjukkan bahwa waktu itu orang sudah memperhatikan kesehatan dan pendidikan.

Amerika Serikat, negara yang kerap kali mempelopori teknik-teknik periklanan modern, baru mengenal iklan pada awal abad ke 18. Iklan iklan media cetak di Amerika Serikat ketika itu ditujukan pada sasaran pembaca di Eropa yang menyebutkan adanya tanah-tanah garapan yang menantang untuk masa depan di Amerika. Salah satu contoh iklan terbaik yang merupakan bukti sejarah yang dikenal di AS adalah iklan yang dimuat di Pennsylvania Evening Post edisi 6 juli 1776. pesan yang disampaikan tidak lain adalah Proklamasi Kemerdekaan Amerika Serikat.

Kemudian sekitar abad ke 17 di Inggris dan abad ke 18 di Amerika, revolusi industri pecah. Modernisme masuk bersama kapitalisme. Terlalu banyak produk yang dihasilkan. Barangbarang ini memerlukan konsumen baru. Dan kemudian munculah biro-biro iklan profesional (agency). Revolusi informasi muncul disepanjang abad ke 19 informasi bukan lagi kebutuhan sekunder atau tersier (fenomena televisi / handphone / telepon) banyak media baru ditemukan.

\subsubsection{Pengertian iklan (Advertising)}

Sebagai konsumen, kita semua adalah sasaran iklan.yang mengisi dari setiap waktu kehidupan kita. Mungkin pada pagi hari anda tidak dibangunkan oleh ayam jago seperti yang masih terjadi pada masyarakat pedesaan, melainkan oleh radio yang telah berbunyi dan tepat pada jam yang anda inginkan.

Iklan memang telah memasuki seluruh bagian dari kehidupan kita. Sebuah iklan yang terletak sepanjang tol menuju bandar udara ditengah-tengah perkampungan penduduk yang dikelilingi daerah persawahan yang hijau dibeli produsen hanya untuk kepentingan iklan. Rumah itu dijebol atapnya agar dapat ditembus kaki besi dengan konstruksi modern untuk membentangkan iklan "Selamat jalan" dari sebuah produsen rokok. Bukan hanya tempat-tempat milik umum, bahkan seluruh bagian tubuh kita pun sudah menjadi sasaran media iklan. Periksalah salah satu kaos oblong saudara. Mungkin salah satu diantaranya ada yang diberikan oleh salah satu produsen mobil, sekolah terkemuka, atau salah satu majalah dan stasiun TV terkenal berterakan nama merk produk dan anda pun dengan senang hati menggunakannya.

Iklan (advertising) berasal dari kata advere yang artinya mengalihkan pikiran dan gagasan pada pihak lain atau disebut juga komunikasi satu arah. Menurut Keppler dan Otto (1986) bahwa iklan adalah suatu penyampaian informasi tentang barang atau gagasan yang menggunakan media non personal yang dibayar. Menurut Spreegel yang dikutip oleh Susanto (1977) mengemukakan bahwa iklan adalah setiap penyampaian informasi tentang barang ataupun gagasan yang menggunakan media non personal yang dibayar menurut Susanto. S. Astrid (1977) bahwa iklan adalah "Suatu proses komunikasi yang mempunyai kekuatan yang sangat penting sebagai alat pemasaran yang membantu menjual barang, memberikan layanan serta gagasan atau ide melalui saluran tertentu dalam bentuk informasi yang persuatif".

Jadi, iklan merupakan suatu bentuk komunikasi atau saran penyampaian pesan dari produsen kepada konsumen melalui berbagai media dengan tujuan untuk mempengaruhi para konsumen agar menggunakan jasa atau barang yang diiklankan.

Iklan berukuran besar lebih menarik, karena dengan ukurannya yang besar dapat memuat lebih banyak gambar, bidang kosong dan bingkai atau garis pinggir. Iklan kecil diantara materi lain yang ada pada halaman yang sama harus berjuang keras untuk mendapatkan perhatian pembaca. Untuk mencapai pengaruh yang maksimal dengan iklan kecil layout harus dibuat sederhana.

Iklan yang ramai dengan kata-kata dan gambar akan susah dibaca, dibandingkan dengan iklan yang hanya terdiri atas satu atau dua kata saja. Saat merencanakan layout sisakan ruang kosong yang cukup, agar iklan tampak kontras dan menonjol. Bila bentuk iklan mendatar atau horizontal, buatlah visualisasi horizontal dengan sepotong kecil tulisan. Bila mengerjakan iklan yang tinggi kecil, visualisasinya juga harus tinggi kecil dengan sebagian tulisannya ditempatkan di bagian bawah.

\subsubsection{Jenis-jenis iklan}

Menurut Buttner (1986, Mass Comunication, as introduction) Iklan Standar adalah iklan yang ditata secara khusus untuk keperluan memperkenalkan barang, jenis-jenis pelayanan untuk konsumen melalui sebuah media, 
tujuannya untuk merangsang motivasi dan minat para pembeli atau para pemakai.

Iklan layanan masyarakat adalah iklan yang bersifat nonprofit, tidak mencari keuntungan akibat pemasangannya kepada khalayak. Tujuannya memberikan informasi, penerangan serta pendidikan kepada masyarakat. Dalam rangka pelayanan dengan mengajak masyarakat untuk berpartisipasi, bersikap positif terhadap pesan yang disampaikan.

Menurut Drs. Liliweri MS, 1992 Iklan Komersial Disebut juga iklan standar yaitu iklan yang ditata secara khusus untuk keperluan memperkenalkan barang dan jasa pelayanan untuk konsumen melalui sebuah media. Iklan ini bertujuan untuk merangsang motif dan minat para pembeli atau konsumen terhadap barang dan jasa yang ditawarkan. Iklan layanan Masyarakat Disebut juga iklan non komersial yang bersifat nonprofit (tidak mencari keuntungan ) yaitu iklan yang umumnya memberikan informasi dan penerangan serta pendidikan kepada masyarakat dalam rangka pelayanan dengan mengajak masyarakat untuk berpartisipasi dan bersikap positif terhadap pesan yang disampaikan.

\subsubsection{Definisi Internet}

Internet merupakan suatu jaringan besar yang terbentuk dari jaringanjaringan dan merupakan kumpulan yang luas dari jaringan komputer besar dan kecil yang saling bersambungan menggunakan jaringan komunikasi yang ada di seluruh dunia.

\subsubsection{Teori Internet}

Sebelum tahun 1960 pertanyaan utama dalam penyelenggaraan suatu sistem komunikas komputer adalah: "Bagaimana mentransimisikan data melewati suatu medium komunikasi dengan handal dan effisien ". Hasil dari perkembangan ini adalah teori informasi, teori sampling, dan beberapa konsep pengolahan signal. Pada pertengahan tahun 1960 dimulai era packet switching, dan pertanyaan pada riset komunikasi komputer menjadi: "bagaimana menyediakan suatu jasa komunikasi melewait jaringanjaringan yang berbeda yang saling terhubung". Hasil dari perkembangan ini adalah pengembangan teknologi internetwork, model protocol layer, datagram dan stream transport service, dan paradigma client server. Internetworking "adalah suatu abstraksi yang kuat yang memperbolehkan pembahasan kompleksitas dari teknologi komunikasi beragam di bawahnya”.
Dengan menyembunyikan detail setiap perangkat keras jaringan dan menyediakan suatu lingkungan komunikasi tingkat tinggi. Tujuan utama dari Internetworking adalah interoperabilitas yang maksimun, yaitu memaksimalkan kemampuan program pada sistem komputer yang berbeda dan sistem jaringan yang berbeda untuk berkomunikasi secara handal dan efisien. Ini akan menunjang ketersediaaan informasi pada sistem komputer dan jaringan yang beragam, baik perangkat lunak, perangkat keras maupun model data dari informasi tersebut. Pada era teknologi saat ini informasi yang cepat dan mudah didapat sangat diperlukan sekali. Penggunaan Internet juga didukung oleh saluran komunikasi yang sudah memadai dimana hampir setiap rumah mempunyai saluran komunikasi telepon sampai dengan perusahaan yang sudah menggunakan saluran komunikasi yang khusus. Hal lain yang timbul di Indonesia saat ini adalah mulai banyaknya Internet Services Provider (penyedia layanan Internet) yang menyediakan fasilitas Internet kepada para pelanggannya.

\subsubsection{Sejarah Internet}

Dua bulan berselang setelah Neil Amstrong melangkah di bulan, terjadi suatu langkah yang besar di UCLA, sewaktu komputer pertama dikoneksikan ke ARPANET. ARPANET mengkoneksikan empat site, diantaranya UCLA, Stanford Research Institute (SRI), UC Santa Barbara, dan University of Utah. Pada tahun 1977, terdapat lebih seratus mainframe dan komputer mini yang terkoneksi ke ARPANET yang sebagian besar masih berada di Universitas. Dengan adanya fasilitas ini, memungkinkan dosen-dosen dan mahasiswa dapat saling berbagi informasi satu dengan lainnya tanpa perlu meninggalkan komputer mereka. Saat ini, terdapat lebih dari 4.000.000 host internet di seluruh dunia. Sejak tahun 1988, Internet tumbuh secara eksponensial, yang ukurannya kira-kira berlipat-ganda setiap tahunnya. Istilah Internet pada mulanya diciptakan oleh para pengembangnya karena mereka memerlukan kata yang dapat menggambarkan jaringan dari jaringan-jaringan yang saling terkoneksi yang tengah mereka buat waktu itu.

\subsubsection{World Wide Web (WWW)}

World Wide Web yang lebih dikenal dengan web, merupakan salah satu layanan yang didapat oleh pemakai komputer yang terhubung ke internet. World wide web adalah sarana 
pembagian informasi antara pengguna jaringan komputer. Web pada awalnya adalah ruang informasi dalam internet. Dengan menggunakan hypertext, pemakai dituntun untuk menemukan informasi dengan mengikuti link yang disediakan dalam dokumen web yang ditampilkan dalam browser web. Web lebih popular bagi khalayak umum dan pemula terutama untuk tujuan pencarian informasi dan melakukan komunikasi diskusi yang menggunakan web sebagai antarmukanya. Internet identik dengan web karena popularitasnya sebagai penyedia informasi dan antarmuka yang dibutuhkan oleh pengguna internet dari masalah informasi sampai komunikasi. Informasi produk dari yang serius sampai dengan yang sampah, dari yang cumacuma sampai yang komersial semuanya ada. Web memudahkan pengguna komputer berinteraksi dengan pelaku internet lainnya dan menelusuri informasi di internet.

\subsubsection{Universal Resource Locater (URL)}

Pada penggunaan WWW, penunjukan suatu sumber informasi menggunakan metode Universal Resource Locater (URL), yang merupakan konsep penamaan lokasi standar dari suatu file, direktori, komputer, lokasi komputernya dan metoda yang digunakan. URL tidak hanya dapat menunjuk ke suatu file tapi dapat juga menunjuk suatu query, dokumen dalam suatu database, atau hasil dari perintah finger atau perintah archie atau yang lainnya. Dengan URL ini didefinisikan lokasi dan metoda pengaksesan file tersebut.

\subsubsection{Hyper Text Transfer Protocol (HTTP)}

Web merupakan terobosan baru bagi teknologi system informasi yang menghubungkan data dari banyak sumber dan layanan yang beragam macamnya di internet. Pengguna tinggal mengklik tombol mousenya pada link-link hypertext yang ada untuk melompat ke dokumendokumen di berbagai lokasi di internet. Link-link sendiri bias mengacu kepada dokumen web, server FTp (File Transfer Protokol), e-mail ataupun layanan-layanan lainnya. Server dan browser web berkomunikasi satu sama lain dengan protocol yang memang dibuat khusus untuk ini, yaitu HTTP. HTTP bertugas menangani permintaan-permintaan (request) dari browser untuk mengambil dokumendokumen web. HTTP bisa dianggap sebagai system yang bermodel Client-Server.

Browser web sebagai Clientnya, mengirimkan permintaan kepada Server Web untuk mengirimkan dokumen-dokumen web yang dikehendaki pengguna. Server Web lalu memenuhi permintaan ini dan mengirimkannya melalui jaringan kepada browser. Setiap permintaan akan dilayani dan ditangani sebagai suatu koneksi terpisah yang berbeda. Semua dokumen web dikirim sebagai file teks biasa. Sewaktu mengirim request kepada web server, browser juga mengirim sedikit informasi tentang dirinya, termasuk jenis-jenis file yang bias dibaca olehnya. Informasi ini lalu digunakan oleh web server untuk menetukan apakah dokumen yang diminta bias dikirimkan kepada browser atau tidak. Isi dokumen, yang jenisnya ditentukan pada header Content-Type (dalam contoh diatas, sebuah file teks dengan format HTML) selanjutnya akan dibaca oleh browser web dan ditampilkan kepada pengguna. Dengan cara ini browser web bias tahu bagaimana ia harus menangani data yang dikirim kepadanya.

HTTP bekerja diatas TCP (Transmision Control Protocol) yang menjamin sampainya data di tujuan dalam urutan yang benar. Bila suatu kesalahan terjadi selama proses pengiriman, pihak pengirim akan mendapat pemberitahuan bahwa telah terhadi ketidak beresan. Karenanya server dan Client tidak harus menyediakan mekanisme untuk memeriksa kesalahan transmisi data, yang berarti mempermudah pekerjaan pemrograman, namun demikian, HTTP tidak memiliki apa yng disebut Session, seperti halnya FTP, yang menjaga hubungan antar Server dan Client secara konsisten. Setiap halaman web yang dikirim akan melibatkan satu proses penyambungan antara Client dan Server, baru kemudian datanya ditransfer. Setelah data selesai ditransfer koneksi antar server dan client akan diputus, sifatnya ini membuat HTTP sering disebut dengan istilah protocol hit-and-run. Suatu halaman web sering kali berisi beberapa file gambar, atau beberapa file-file lain.

HTTP memaksa Server untuk menjalin hubungan baru setiap kali hendak mengirim satu buah file. Ini tidak menguntungkan dan tidak efisien, mengingat proses hubung-putus-hubung semacam ini menyebabkan beban bagi jarinagan. Standar baru protocol baru HTTP, yaitu HTTP/1.1 yang baru-baru ini diperkenalkan, dirancang untuk emngatasi masalh diatas. Web diarahkan agar mengarah kepenggunaan 
persistent conection (sambungan yang terjaga kesinambungan) secara lebih efisien. Dalam HTTP/1.1, Server tidak akan memutus hubungan dengan Client pada akhir pentrasnferan dokumen. Hubungan tetap dibuka untuk melayani bila saja ada request lagi dalam waktu yang singkat hubungan baru akan diputuskan bila setelah melewati batas waktu tertentu (yang bias ditentukan oleh administrator server) client tidak mengirmkan request lagi. Keuntungan lain dari persistent conection adalah penggunaan pipelining. Pipelining adalah proses pengiriman request berikutnya segera setelah request sebelumnya dikirim tanpa menunggu balasan server terlebih dahulu servernya tetap harus melayani request secara berurutan, namun ini mengurangi waktu tunda antara setiapm request hasilnya, datanya akan lebih cepat sampai ditujuan. Standar HTTP/1.1 ini sekarang sudah mulai di masyarakatkan dan banyak perangkat lunak server web komersil dan non komersil yang sudah mendukung standar baru ini. Browserbrowser web keluaran terbaru umunya juga sudah mendukung HTTP/1.1.

\subsubsection{Definisi Efektivitas}

Menurut kamus besar bahasa Indonesia (2002: 284), efektiv adalah ada efeknya (akibatnya,pengaruh,kesannya) ; dapat membawa hasil atau berhasil guna (tentang usaha,tindakan). Definisi efektivitas menurut Aras (2003: 29), adalah suatu keadaan dimana kemampuan suatu sistem sesuai keinginan dari pengguna.

Roulette (1999:1), "Efektifitas adalah dengan melakukan hal yang benar pada saat yang tepat untuk jangka waktu yang panjang, baik pada organisasi tersebut dan pelanggan".

Hodge (1984:299), "Efektifitas sebagai ukuran suksesnya organisasi didefinisikan sebagai kemampuan organisasi untuk mencapai segala keperluannya. Ini berarti bahwa organisasi mampu menyusun dan mengorganisasikan sumber daya untuk mencapai tujuan".

Abdurahmat (2003:92), "Efektifitas adalah pemanfaatan sumber daya, sarana dan prasarana dalam jumlah tertentu yang secara sadar ditetapkan sebelumnya untuk menghasilkan sejumlah pekerjaan tepat pada waktunya".

Sondang P. Siagian (2001:24), "Efektifitas adalah pemanfaatan sumber daya, sarana dan prasarana dalam jumlah tertentu yang secara sadar ditetapkan sebelumnya untuk menghasilkan sejumlah barang atas jasa kegiatan yang dijalankannya”.
Berdasarkan pendapat di atas dapat disimpulkan bahwa efektifitas merupakan suatu ukuran ketercapaian dalam jumlah tertentu sesuai dengan keadaan sesungguhnya dari satu pekerjaan tertentu.

\subsubsection{Difinisi PHP}

PHP adalah kependekan dari PHP Hypertext Preprocessor, bahasa Interpreter yang mirip dengan Bahasa $\mathrm{C}$ dan Perl yang memiliki kesederhanaan dalam perintah. PHP dapat digunakan bersama dengan HTML sehingga memudahkan dalam pembangunan aplikasi web dengan cepat. PHP dapat digunakan meng-update basis data dan menciptakan basis data. Interpreter adalah sebuah program yang digunakan untuk membaca file yang berisi kode program yang akan dijalankan, kemudian Interpreter tersebut akan meminta CPU untuk melakukan perintah yang diterima.

Seperti halnya program open source lainnya, PHP dibuat di bawah lisensi GNU, General Public Lisence, yang dapat di-download gratis melalui situs http://www.php.net. Awalnya, PHP diciptakan oleh Andi Gutmans untuk menghitung jumlah pengunjung yang mengakses homepage yang dibuatnya. Namun, seiring dengan perkembangan Internet, dirilis PHP/F1, PHP2, PHP3, PHP4, dan selanjutnya PHP5. PHP5 telah mampu digunakan untuk membangun aplikasi web dengan koneksi basis data yang cukup banyak. PHP5 adalah versi pengembangan dari PHP4 dengan menambahkan fungsi-fungsi seperti Zend Engine (http://www.zend.com) sehinggan akses lebih cepat, kuat, stabil, serta mudah untuk berinteraksi dengan berbagai aplikasi pendukung lainnya.

PHP banyak mendukung basis data, seperti MySQL, PostgresSQL, Interbase, ODBC, mSQL, dan Sybase. Kini, PHP4 banyak digunakan oleh para web developer untuk membangun aplikasi web karena memang terbukti dapat bekerja dengan baik (Iswanto,ST 2007 : 2).

\subsubsection{MySQL}

MySQL adalah sebuah perangkat lunak sistem manajemen basis data SQL (bahasa Inggris: database management system) atau DBMS yang multithread, multi-user, dengan sekitar 6 juta instalasi di seluruh dunia. MySQL AB membuat MySQL tersedia sebagai perangkat lunak gratis di bawah lisensi GNU General Public License (GPL), tetapi mereka juga menjual dibawah lisensi komersial untuk kasus-kasus 
dimana penggunaannya tidak cocok dengan penggunaan GPL. Tidak seperti PHP atau Apache yang merupakan software yang dikembangkan oleh komunitas umum, dan hak cipta untuk kode sumber dimiliki oleh penulisnya masing-masing, MySQL dimiliki dan disponsori oleh sebuah perusahaan komersial Swedia yaitu MySQL AB. MySQL AB memegang penuh hak cipta hampir atas semua kode sumbernya. Kedua orang Swedia dan satu orang Finlandia yang mendirikan MySQL AB adalah: David Axmark, Allan Larsson, dan Michael "Monty" Widenius.

Fitur-fitur MySQL antara lain:

1. Relational Database System. Seperti halnya software database lain yang ada di pasaran, MySQL termasuk RDBMS.

2. Arsitektur Client-Server. MySQL memiliki arsitektur client-server dimana server database MySQL terinstal di server. Client MySQL dapat berada di komputer yang sama dengan server, dan dapat juga di komputer lain yang berkomunikasi dengan server melalui jaringan bahkan internet.

3. Mengenal perintah SQL standar. SQL (Structured Query Language) merupakan suatu bahasa standar yang berlaku di hampir semua software database. MySQL mendukung SQL versi SQL:2003.

4. Mendukung Sub Select. Mulai versi 4.1 MySQL telah mendukung select dalam select (sub select).

5. Mendukung Views. MySQL mendukung views sejak versi 5.0

6. Mendukung Stored Prosedured (SP). MySQL mendukung SP sejak versi 5.0

7. Mendukung Triggers. MySQL mendukung trigger pada versi 5.0 namun masih terbatas. Pengembang MySQL berjanji akan meningkatkan kemampuan trigger pada versi 5.1.

8. Mendukung replication.

9. Mendukung transaksi.

10. Mendukung foreign key.

\subsubsection{Definisi UML Diagram}

Unified Modeling Language atau UML adalah bahasa pemodelan grafis yang sebagian besar digunakan untuk mengekspresikan desain.
Ini adalah bahasa standar di mana untuk menentukan artefak dan komponen dari sistem perangkat lunak. Penting untuk memahami bahwa UML menggambarkan notasi dan bukan proses. Ini tidak mengajukan sebuah metode tunggal atau proses desain, melainkan adalah alat standar yang dapat digunakan dalam proses desain. (http://visualcase.com/tutorials/uml-tutorial.html) diakses tanggal 10-juni-2012)

Menurut (Hend, 2006) "Unified Modeling Language (UML) adalah bahasa yang telah menjadi standard untuk visualisasi, menetapkan, membangun dan mendokumentasikan artifak suatu sistem perangkat lunak".

Model UML terdiri atas banyak elemenelemen grafis yang digabungkan membentuk diagram.Tujuan representasi elemen elemen grafis ke dalam diagram adalah untuk menyajikan beragam sudut pandang dari sebuah sistem berdasarkan fungsi masing-masing diagram tersebut.

Ada 4 (empat) macam diagram dalam Unified Modeling Language (UML), yaitu :

a. Use Case Diagram

Diagram ini memperihatkan himpunan use case dan aktor-aktor (suatu jenis khusus dari kelas). Diagram ini terutama sangat penting untuk mengorganisasi dan memodelkan perilaku dari suatu sistem yang dibutuhkan serta diharapkan pengguna.

b. Class Diagram

Diagram ini memperlihatkan himpunan kelas-kelas, antarmuka-antarmuka, kolaborasi-kolaborasi dan relasi-relasi antar objek.

c. Sequence Diagram

Diagram ini memperlihatkan interaksi yang menekankan pada pengiriman pesan (message) dalam suatu waktu tertentu.

d. Activity Diagram

Diagram ini memperlihatkan aliaran dari suatu aktifitas ke aktifitas lainnya dalam suatu sistem. Diagram ini terutama penting dalam pemodelan fungsi-fungsi dalam suatu sistem dan memberi tekanan pada aliran kendali antar objek.

\subsubsection{Notasi dalam UML}

a. Actor 


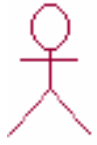

Gambar 2.5 Notasi Actor

Actor menggambarkan segala pengguna software aplikasi (user). Actor memberikan suatu gambaran jelas tentang apa yang harus dikerj akan software aplikasi. Sebagai contoh sebuah actor dapat memberikan input kedalam dan menerima informasi dari software aplikasi, perlu dicatat bahwa sebuah actor berinteraksi dengan use case, tetapi tidak memiliki kontrol atas use case. Sebuah actor mungkin seorang manusia, satu device, hardware atau sistem informasi lainnya.

\section{b. Use Case}

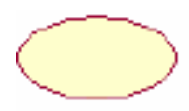

Gambar 2.6 Notasi Use Case

Use case menjelaskan urutan kegiatan yang dilakukan actor dan sistem untuk mencapai suatu tujuan tertentu. Walaupun menjelaskan kegiatan, namunuse case hanya menjelaskan apa yang dilakukan oleh actor dan sistem bukan bagaimana actor dan sistem melakukan kegiatan tersebut.

- Use-case Konkret adalah use case yang dibuat langsung karena keperluan actor. Actor dapat melihat dan berinisiatif terhadapnya

- Use-case Abstrak adalah use case yang tidak pernah berdiri sendiri. Use case abstrak senantiasa termasuk didalam (include), diperluas dari (extend) atau memperumum (generalize) use case lainnya.

Untuk menggambarkannya dalam use case model biasanya digunakan association relationship yang memiliki stereotype include, extend atau generalization relationship. Hubungan include menggambarkan bahwa suatu use case seluruhnya meliputi fungsionalitas dari use case lainnya. Hubungan extend antar use case berarti bahwa satu use case merupakan tambahan fungsionalitas dari use case yang lain jika kondisi atau syarat tertentu terpenuhi.

\section{c. Class}

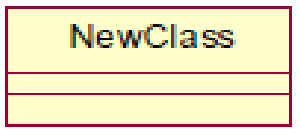

Gambar 2.7 Notasi Class

Class merupakan pembentuk utama dari sistem berorientasi obyek, karena class menunjukkan kumpulan obyek yang memiliki atribut dan operasi yang sama. Class digunakan untuk mengimplementasikan interface. Class digunakan untuk mengabstraksikan elemenelemen dari sistem yang sedang dibangun. Class bisa merepresentasikan baik perangkat lunak maupun perangkat keras, baik konsep maupun benda nyata. Notasi class berbentuk persegi panj ang berisi 3 bagian: persegi panjang paling atas untuk nama class, persegi panj ang paling bawah untuk operasi, dan persegi panjang ditengah untuk atribut. Atribut digunakan untuk menyimpan informasi. Nama atribut menggunakan kata benda yang bisa dengan jelas merepresentasikan informasi yang tersimpan didalamnya. Operasi menunj ukkan sesuatu yang bisa dilakukan oleh obyek dan menggunakan kata kerja.

\section{d. Interface}

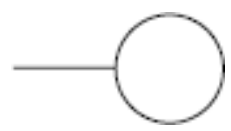

Gambar 2.8 Notasi Interface

Interface merupakan kumpulan operasi tanpa implementasi dari suatu class. Implementasi operasi dalam interface dijabarkan oleh operasi didalam class.Oleh karena itu keberadaan interface selalu disertai oleh class yang mengimplementasikan operasinya. I nterface ini merupakan salah satu cara mewujudkan prinsip enkapsulasi dalam obyek.

\section{e. Interaction}

\section{Gambar 2.9 Notasi Interaction}

Interaction digunakan untuk menunjukkan baik aliran pesan atau informasi antar obyek 
maupun hubungan antar obyek. Biasanya interaction ini dilengkapi juga dengan teks bernama operation signature yang tersusun dari nama operasi, parameter yang dikirim dan tipe parameter yang dikembalikan.

\section{f. Note}

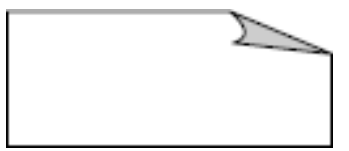

Gambar 2.10 Notasi Note

Note digunakan untuk memberikan keterangan atau komentar tambahan dari suatu elemen sehingga bisa langsung terlampir dalam model. Note ini bisa disertakan ke semua elemen notasi yang lain.

\section{g. Dependency}

Gambar 2.11 Notasi Dependency

Dependency merupakan relasi yang menunj ukan bahwa perubahan pada salah satu elemen memberi pengaruh pada elemen lain. Elemen yang ada di bagian tanda panah adalah elemen yang tergantung pada elemen yang ada dibagian tanpa tanda panah. Terdapat 2 stereotype dari dependency, yaitu include dan extend. Include menunj ukkan bahwa suatu bagian dari elemen (yang ada digaris tanpa panah) memicu eksekusi bagian dari elemen lain (yang ada di garis dengan panah). Extend menunjukkan bahwa suatu bagian dari elemen di garis tanpa panah bisa disisipkan kedalam elemen yang ada di garis dengan panah.

\section{h. Association}

\section{Gambar 2.12 Notasi Asociation}

Association menggambarkan navigasi antar class (navigation), berapa banyak obyek lain yang bisa berhubungan dengan satu obyek (multiplicity antar class) dan apakah suatu class menjadi bagian dari class lainnya (aggregation). Navigation dilambangkan dengan penambahan tanda panah di akhir garis. Bidirectional navigation menunjukkan bahwa dengan mengetahui salah satu class bisa didapatkan informasi dari class lainnya. Sementara UniDirectional navigation hanya dengan mengetahui class diuj ung garis association tanpa panah kita bisa mendapatkan informasi dari class di ujung dengan panah, tetapi tidak sebaliknya. Aggregation mengacu pada hubungan has-a , yaitu bahwa suatu class memiliki class lain, misalnya Rumah memiliki class Kamar.

\section{i. Generalization}

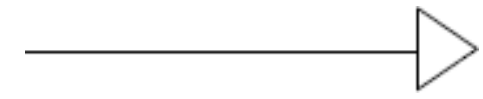

Gambar 2.13 Notasi Generalization

Generalization menunjukkan hubungan antara elemen yang lebih umum ke elemen yang lebih spesifik. Dengan generalization, class yang lebih spesifik(subclass) akan menurunkan atribut dan operasi dari class yang lebih umum (superclass) atau subclass is superclass. Dengan menggunakan notasi generalization ini, konsep inheritance dari prinsip hirarki dapat dimodelkan.

\section{j. Realization}

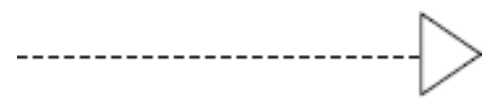

Gambar 2.14 Notasi Realization

Realization menunjukkan hubungan bahwa elemen yang ada di bagian tanpa panah akan merealisasikan apa yang dinyatakan oleh elemen yang ada di bagian dengan panah. Misalnya class merealisasikan package, component merealisasikan class atau interface.

\section{k. Package}

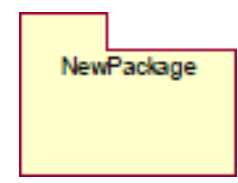

Gambar 2.15 Notasi Package (Paket) 
Paket adalah mekanisme pengelompokkan yang dgunakan untuk menandakan pengelompokkan elemen-elemen model. Sebuah paket dapat mengandung beberapa paket lain didalamnya. Paket digunakan untuk memudahkan mengorganisasikan elemen-elemen model.

\section{l. Relationship}

Adalah koneksi antar model elemen.

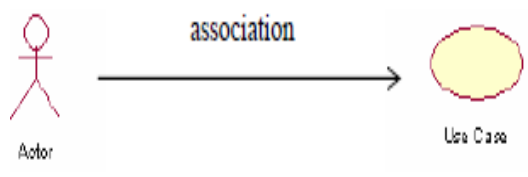

Gambar 2.16 Association Relationship

Association Relationship, memodelkan koneksi antar obyek dari kelas yang berbeda. I nteraksi antara actor dan use-case dalam use-case model biasanya digunakan association relationship yaitu :

$$
\text { <<uses>> }
$$

Hubungan uses menunjukkan bahwa prosedur dari use-case merupakan bagian dari prosedur yang menggunakan use-case. Tanda panah menunjukkan keadaan tidak mengakibatkan pemanggilan prosedur dalam menggunakan use-case. Relasi uses antara usecase ditunj ukkan dengan panah generalisasi dari use-case. Use-case yang dilakukan secara berulang, digunakan untuk meminimalkan pekerjaan.

$$
<<\text { extend }>>
$$

Hubungan extend antar use-case berarti bahwa suatu use-case merupakan tambahan kegunaan dari use-case yang lain jika kondisi atau syarat tertentu dipenuhi. Jika prosedur dari usecase merupakan alternatif untuk menjelaskan usecase lain. Use-case akan dikerjakan apabila salah satu syarat terpenuhi. Hubungan generalisasi antar use-case menunj ukkan bahwa use-case yang satu merupakan spesialisai dari yang lain.

$$
\text { <<include>> }
$$

Hubungan include menggambarkan suatu use-case seluruhnya meliputi kegunaan dari usecase lainnya. Sebuah use-case dapat meng-include fungsionalitas use-case lain sebagai bagian dari proses dalam dirinya. Secara umum diasumsikan bahwa use-case yang di-include dieksekusi secara normal. Sebuah use-case dapat di-include oleh lebih dari use-case lain, sehingga duplikasi fungsional dapat dihindari.

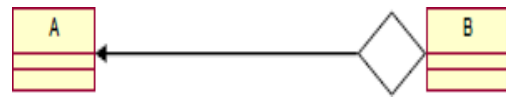

Gambar 2.17 Aggregation Relationship

Aggregation Relationship, adalah bentuk khusus assosiasi yang memodelkan hubungan keanggotaan antara 2 kelas, yakni satu kelas disusun oleh kelas lainnya. Gambar diatas memperlihatkan bahwa B (kelas aggregate) yang secara fisik dibentuk oleh $\mathrm{A}$ atau secara logis B mengandung A.

\subsubsection{Pengertian Flowchart}

Flowchart merupakan penyajian yang sistematis tentang proses dan logika dari kegiatan penanganan informasi. (Widia, 1983:4)

\subsubsection{Kerangka Pemikiran}

Tabel 2.19 Kerangkan pemikiran Keterangan:

Dari tabel kerangka pemikiran tersebut dapat diuraikan proses demi proses dengan rincian sebagai berikut:

a. Permasalahan (problems), permasalahan yang diteliti adalah dengan mengunakan brosur biasa penyebaranya hanya terbatas pada daerah tertentu, dengan mengunakan brosur biasa dibutuhkan biaya yang cukup tinggi dalam membuatnya dengan mengunakan brosur biasa banyak penerima informasi yang tidak membutuhkan informasi tersebut penyebaran brosur dan iklan cetak kurang efektif.

b. Pendekatan (Approach), pendekatan yang digunakan untuk memecahkan masalah tersebut menggunakan Modern Advertising Methods Atau Metode Periklanan Modern unuk mendukung periklanan.

c. Pengembangan Aplikasi (Software Development), digunakan sebagai alat bantu untuk membuat aplikasi website e-brosur.

d. Implementasi (Implementation), untuk membantu mengukur keefektifan $e$-brosur.

e. Pengukuran (Measurement), digunakan untuk membantu melihat hasil pemilihan dari mengunakan pretest dan posttest.

Hasil (Result), digunakan untuk melihat hasil akhir rangkaian proses penelitian dan tujuan akhir 
yang dicapai yaitu dengan adanya sistem portal ebrosur dapat mempercepat proses periklanan dengan mengunakan media internet dalam bentuk e-brosur mengurangi biaya pemasaran dengan membuat aplikasi portal e-brosur yang mengurangi biaya brosur cetak membuat aplikasi portal e-brosur yang akan membantu pencari iklan dan menemukan iklan yang akan di cari, sehingga lebih tepat sasaran mengurangi penggunaan kertas dengan mengunakan sistem portal e-brosur ini dan mengukur tingkat keefektivitasan e-brosur.

\subsection{Metodologi Penelitian}

Metode penelitian yang digunakan dalam penelitian ini adalah deskriptif research, yaitu metode penelitian yang membuat gambaran mengenai permasalahan yang telah diidentifikasi oleh penulis, dimana objek yang diteliti dijelaskan dari sudut pandang penulis Cook and Reichardt (1979). Selanjutnya dilakukan pencarian data sekunder yang ada di lapangan melalui berbagai media, seperti : internet, buku literatur, jurnal, dan artikel sehingga didapatkan informasi yang akurat mengenai parameter penilaian penelitian untuk perancangan aplikasi.

\subsection{Metode Pemilihan Sampel}

Menurut Kamus Pelajar terbitan Pusat Bahasa Departemen Pendidikan Nasional tahun 2003, populasi adalah jumlah orang atau penduduk dalam suatu daerah, jumlah penghuni baik manusia maupun makhluk hidup lainnya pada suatu tempat atau ruang tertentu. Populasi menurut Gay (1987:102) merupakan kelompok tertentu dari sesuatu (orang, benda, peristiwa, dan sebagainya) yang dipilih oleh peneliti yang hasil studinya atau penelitiannya dapat digeneralisasikan terhadap kelompok tersebut. Suatu populasi sedikitnya mempunyai satu karakteristik yang membedakannya dengan kelompok yang lain.

Sampel adalah sebagian atau wakil dari populasi yang diteliti (Arikunto, 2006:131). Mardalis (2009:55) menyatakan sampel adalah contoh, yaitu sebagian dari seluruh individu yang menjadi objek penelitian. Jadi sampel adalah contoh yang diambil dari sebagain populasi penelitian yang dapat mewakili populasi. Walaupun yang diteliti adalah sampel, tetapi hasil penelitian atau kesimpulan penelitian berlaku untuk populasi atau kesimpulan penelitian digeneralisasikan terhadap populasi. Yang dimaksud menggeneralisasikan adalah mengangkat kesimpulan penelitian dari sampel sebagai sesuatu yang berlaku bagi populasi.

Dalam penelitian ini, yang menjadi batasan populasi didalam penelitian ini adalah User, yaitu individu yang menggunakan sistem untuk melakukan fungsi tertentu. Populasi penelitian dari user adalah Mebuat brosur cetak dan iklan seluruhnya sejumlah 10 orang.

\subsection{Teknik Pengumpulan Data}

Metode yang digunakan di dalam penelitian adalah metode deskriptif analitik, dengan menyajikan rangkuman hasil survei dan wawancara yang berupa kuisioner. Kemudian hasil wawancara pada penelitian ini, alat yang digunakan untuk pengukuran data adalah kuesioner yang diisi melalui observasi. Hal ini akan lebih efektif jika informasi yang hendak diambil berupa kondisi atau fakta alami, tingkah laku dan hasil kerja responden dalam situasi

\begin{tabular}{|c|l|c|c|}
\hline No & \multicolumn{1}{|c|}{ Pertanyaan } & Benar & $\begin{array}{c}\text { Tidak } \\
\text { Benar }\end{array}$ \\
\hline 1 & $\begin{array}{l}\text { Penyebaran brosur atau } \\
\text { iklan cetak adalah cara } \\
\text { efektif untuk mencapai } \\
\text { sasaran yang diharapkan }\end{array}$ & $\begin{array}{l}\text { Biaya pembuatan brosur } \\
\text { atau iklan cetak cukup } \\
\text { besar }\end{array}$ & $\begin{array}{l}\text { Pembuatan brosur atau } \\
\text { iklan memakan waktu yang } \\
\text { cukup lama }\end{array}$ \\
\hline 4 & $\begin{array}{l}\text { Penyebaran brosur dan } \\
\text { iklan cetak kurang efektif }\end{array}$ & & \\
\hline 3 & & \\
\hline
\end{tabular}

alami. Dalam penelitian kuantitatif, instrumen observasi lebih sering digunakan sebagai alat pelengkap instrumen lain, termasuk kuesioner dan wawancara. Untuk memperoleh item kuesioner yang baik, terdapat beberapa hal yang harus diperhatikan yaitu:

a. Setiap item harus dibuat dengan bahasa yang jelas dan tidak mempunyai arti yang meragukan.

b. Peneliti hendaknya menghindari pertanyaan atau pernyataan ganda dalam satu item.

c. Item pertanyaan atau pernyataan berkaitan dengan permasalahan yang hendak dipecahkan dalam penelitian.

d. Bahasa yang digunakan hendaknya menggunakan bahasa yang baku.Peneliti hendaknya tidak terlalu mudah 
menggunakan item-item negatif atau item yang menjebak responden.

e. Peneliti hendaknya membangun item kuesioner yang terarah dalam kisi-kisi kerja atau framework permasalahan.

Faktor-faktor yang digunakan sebagai parameter untuk mengukur mempercepat aktivitas berbagi pengtahuan di perusahaan atau pun tempat objek adalah partisipasi, motivasi, kemudahan, dan waktu.

Pertanyaan-pertanyaan tersebut diukur dengan skala nominal, skala ini berfungsi untuk menunjukkan tingkat kepuasan responden terhadap hal yang ditanyakan. Pengukuran dengan skala nominal merupakan tingkat mengkategorikan, memberi nama dan menghitung fakta-fakta dari obyek yang diteliti. Dimana angka yang diberikan pada obyek hanya mempunyai arti sebagai label saja dan tidak menunjukkan tingkatan yang berarti. Skala nominal akan menghasilkan data yang disebut data nominal atau data diskrit, yaitu data yang diperoleh dari mengkategorikan, memberi nama dan menghitung fakta-fakta dari objek yang diobservasi dengan deskripsi sebagai berikut:

a. Benar menyatakan sangat setuju.

b. Tidak Benar menyatakan tidak setuju. Contoh : Benar dan Tidak Benar.

Tabel 3.1

Contoh Tabel Kuesioner

Setelah melakukan penyebaran kuesioner maka telah mendapatkan hasilnya adalah:

a. 6 orang memilih benar dan 4 orang memilih tidak benar.

b. 7 orang memilih benar dan 3 orang memilih tidak benar

c. 2 orang memilih benar dan 8 orang memilih tidak benar

d. 6 orang memilih benar dan 4 orang memilih tidak benar.

\subsection{Perancangan Penelitian}

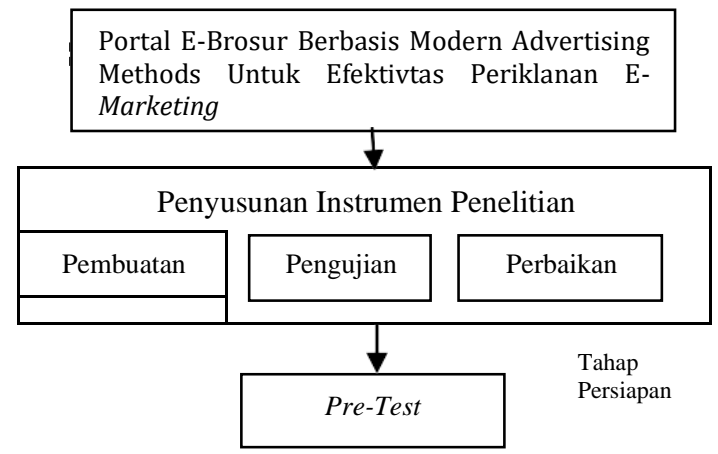

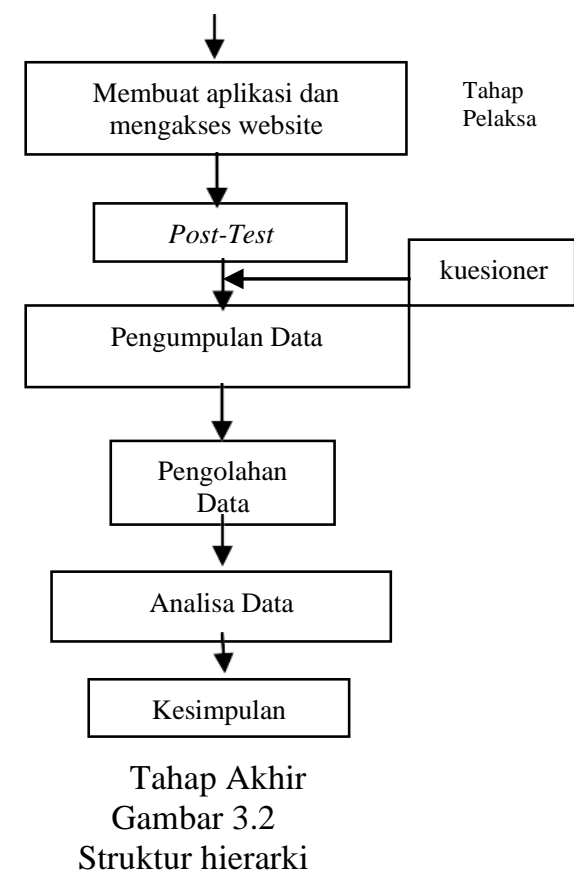

\subsection{Unified Modeling Language (UML) Diagram}

Kumpulan dari beragam sudut pandang inilah yang disebut sebuah model. $U M L$ yang dipakai di penelitian ini sebagai berikut:

1. Use Case Diagram

2. Activity Diagram

3. Sequence Diagram

\subsubsection{Use Case}

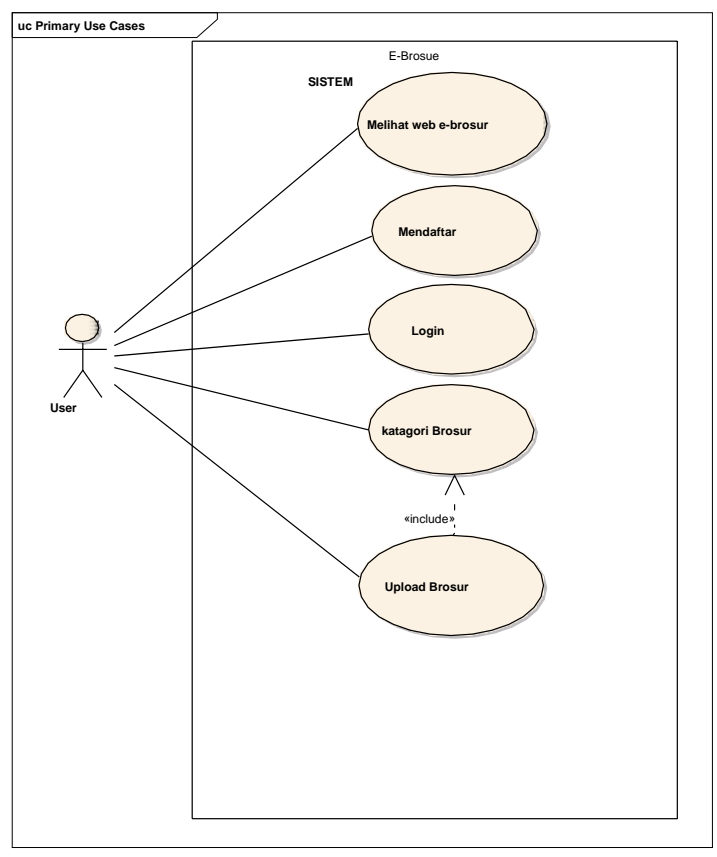


Gambar 3.3 Use Case Diagram

Keterangan:

User melihat e-brosur ketika ada yang sesuai keinginan maka user akan mendaftar diri untuk bisa login setelah itu akan masuk ke dalam home atau halaman utama danbisam memilih menu yang admin sediakan contohnya bisa melihat katagori brosur kemudian bisa mengupload dan download brosur yang dipilih atau yang diinginkan.

\subsubsection{ActivityDiagram.}

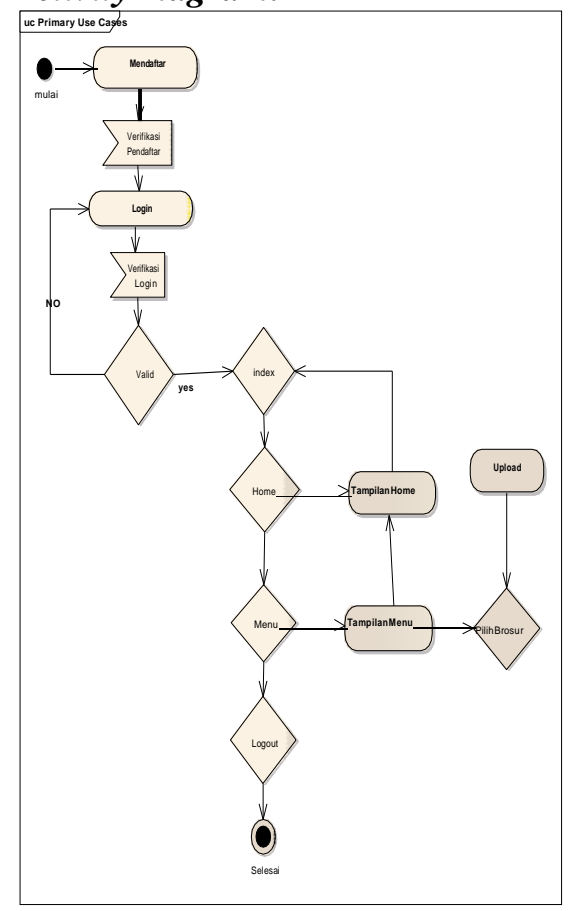

Gambar 3.4 Activity Diagram

Keterangan:

User mendaftar di website akan di verifikasi email setelah itu akan diproses langsung login di website kemudian akan verifikasi login jika valid maka akan masuk ke website dan akan muncul home pilih menu kemudian user akan memilih brosur untuk download atau menupload brosur.

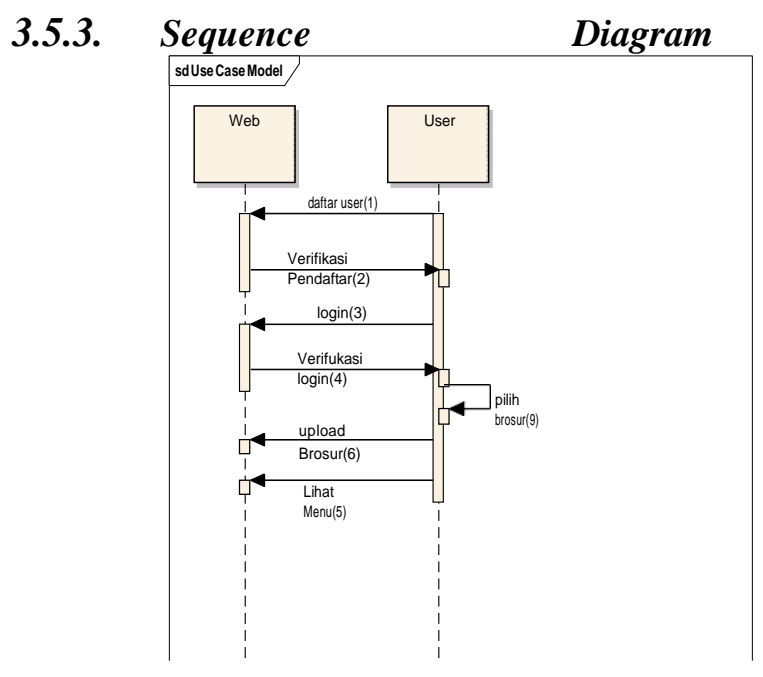

Gambar 3.5 Sequence Diagram

Keterangan:

User mendaftarkan diri kemudian akan diverifikasi pendaftaran kemudian login jika valid maka akan masuk ke halaman menu, user memilih menu brosur kemudian terjadi aktifitas apakah user hanya membaca informasi ataupun menupload atau download.

\subsection{Pengujian Aplikasi}

Pengujian Aplikasi di uji melalui teknik pengujian perangkat lunak yang meliputi pengujian aplikasi pengujian white box dan black box.

1. Pengujian Aplikasi Pengujian White Box Metode white box ini adalah suatu metode desain test case yang menggunakan struktur kontrol desain prosedural untuk memperoleh test case. Dengan menggunakan metode pengujian white box, perekayasaan sistem dapat melakukan test case yang dapat:

a. Memberikan jaminan bahwa semua jalur independen pada suatu modul telah digunakan paling tidak satu kali.

b. Menggunakan semua keputusan logis pada sisi true dan false.

c. Mengeksekusi semua loop (perulangan) pada batasan mereka dan pada batas operasional mereka.

Dalam hal ini, pengujian tidak dilakukan terhadap keseluruhn program secara utuh, namun 
dilakukan sampel pengujian terhadap proses tertentu. Pengujian white Box terhadap proses konfigrasui bobot, secara garis besar, algoritma dari proses login adalah sebagai berikut.

a. Masukan nilai karakteristik.

b. Jika jumlah mencapai $100 \%$.

c. Bila terjadi kurang atau lebih dari 100 persen dari total tampilkan pesan kesalahan.

d. Lakukan pengisian data baru seperti langkah (a).

e. Bila telah mencapai total $100 \%$, maka user dapat mengakses sistem.

Basis set yang dihasilkan dari jalur independent secara linier adalah jalur sebagai berikut: $\mathrm{a}-\mathrm{b}-\mathrm{c}-\mathrm{d}-\mathrm{e} \mathrm{a}-\mathrm{b}-\mathrm{a}-\mathrm{b}-\mathrm{c}-\mathrm{d}-\mathrm{e} \mathrm{a}$ $-\mathrm{b}-\mathrm{c}-\mathrm{d}-\mathrm{a}-\mathrm{b}-\mathrm{c}-\mathrm{d}-\mathrm{e}$. Ketika aplikasi dijalankan, maka terlihat bahwa salah satu basis set yang dihasilkan adalah $\mathrm{a}-\mathrm{b}-\mathrm{c}-\mathrm{d}-\mathrm{e}$ dan terlihat bahwa simpul telah dieksekusi satu kali. Berdasarkan ketentuan tersebut dari segi kelayakan software, sistem ini telah memenuhi syarat. Adapun untuk level 2, alur jalannya permainan sama dengan level 1 , hanya berubah objek yang dikumpulkan. Jadi dapat dikatakan bahwa hasil pengujian untuk level 2 juga telah memenuhi syarat.

2. Pengujian Aplikasi Pengujian Blcak Box

Pengujian selanjutnya dilakukan untuk memastikan bahwa suatu event atau masukan akan menjalankan proses yang tepat dan menghasilkan output sesuai dengan rancangan. Untuk contoh pengujian terhadap beberapa perintah sebagai berikut :

Kuesioner tersebut diisi oleh pengguna internet 5 orang responden dan dibagikan dua kali yaitu pada saat sebelum menggunakan aplikasi perangkat lunak serta setelah diimplementasikannya Aplikasi Perangkat Lunak. Website portal e-brosur langkah-langkah pengujian sebagai berikut :

a. Menentukan Hipotesis

Ho : Tidak ada perbedaan antara pre-test (sebelum menggunakan aplikasi) dengan Post-Test (setelah penggunaan aplikasi).

b. Menentukan tingkat signifikansi Pengujian menggunakan uji dua sisi dengan tinggal signifikansi a: $5 \%$. Tingkat signifikansi dalam hal ini berarti kita mengambil risiko salah dalam mengambil keputusan untuk menolak hipotesis yang benar sebanyak-banyaknya $5 \%$

(signifikansi $5 \%$ atau 0,05 adalah ukuran standar yang sering digunakan dalam penelitian).

c. Menentukan t hitung

Dapat dilihat dari hasil analisis uji $T$ Test, dalam hal ini menggunakan software SPSS 15 untuk mengnalisis Uji $T$ Test tersebut.

d. Menentukan T Tabel

Tabel distribusi t dicari pada $\mathrm{a}=5 \%$

: $2=2,5 \%$ (uji 2 sisi) dengan derajat kebebasan (df) n-1.

e. Kriteria Pengujian

Ho diterima jika $-\mathrm{t}$ tabel $\leq \mathrm{t}$ hitung $\leq \mathrm{t}$ tabel Ho ditolak jika $-\mathrm{t}$ hitung $<$ - $\mathrm{t}$ tabel atau $\mathrm{t}$ hitung $>\mathrm{t}$ tabel Berdasar probabilitas : Ho diterima jika $\mathrm{P}$ value $>0,05$ Ho ditolak jika $\mathrm{P}$ value $<0,05$.

\subsection{Cyclomatic Complexcity}

Cyclomatic Complexity merupakan suatu sistem pengukuran yang menyediakan ukuran kuantitatif dari kompleksitas logika suatu program. Pada Basis Path Testing, hasil dari cyclomatic complexity digunakan untuk menentukan banyaknya independent paths. Independent path adalah sebuah kondisi pada program yang menghubungkan node awal dengan node akhir.

\subsection{Hasil}

Hasil perancangan aplikasi website Portal E-Brosur dengan menggunakan dreamweaver 8 dan XAMPP sebagai editor bahasa pemrograman PHP dan MYSQL.

\subsection{Spesifikasi Sistem Aplikasi}

Spesifikasi sistem aplikasi dibagi menjadi dua yaitu :

a. Perangkat Keras dan Perangkat Lunak

Spesifikasi perangkat keras (hardware)

di bawah ini dapat menjadi acuan untuk implementasi Aplikasi website Portal E-Brosur.

1. Processor intel core 2 duo atau lebih,

2. RAM dengan kapasitas $1 \mathrm{~GB}$ atau lebih,

3. Harddisk dengan kapasitas $120 \mathrm{~GB}$ atau lebih, Mouse, Keyboard,

4. Monitor.

Sedangkan untuk perangkat lunak untuk mendukung aplikasi ini yaitu:.

a. Adobe Dreamweaver Creative Suite 3 Master atau dreamweaver 8.

b. XAMPP 
5. Instalasi Sistem

Untuk menjalankan aplikasi website Portal E-Brosur, perlu melakukan langkah-langkah sebagai berikut.

a.Install Sistem Operasi.

Sistem operasi yang digunakan adalah microsoft windows 8 atau bisa juga windows lainnya.

b. Instal Adobe Dreamweaver Creative Suite 3 Master.

Adobe Dreamweaver Creative Suite 3 Master merupakan kumpulan dari design grafis, video editing, dan pengembangan aplikasi website yang di buat oleh Adobe System dan penulis memilih dreamweaver 8 sebagai aplikasi pendukung.

\subsection{Antar Muka Pengguna}

Graphical User Interface (GUI) merupakan antar muka pengguna suatu program berbasis grafis, yakni perintah-perintah tidak diketik melalui key board, berikut adalah beberapa tampilan antar pengguna untuk berinteraksi dengan system.

\subsection{Tampilan Awal Aplikasi Website Portal E-Brosur}

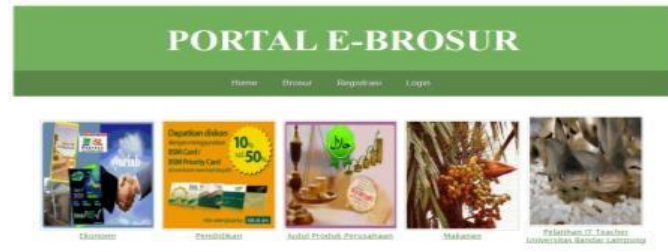

Gambar 4.1 Portal E-Brosur

Form ini adalah form awal dari website Portal EBrosur yang di gunakan untuk melihat brosur.

a From Menu

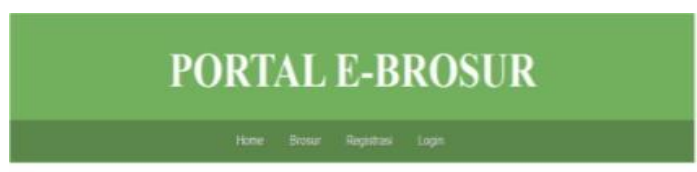

Brosur Berdasarkan Kategori

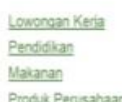

b From Brosur

\section{PORTAL E-BROSUR}

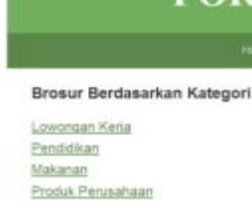

Gambar 4.3 Form Brosur

\section{PORTAL E-BROSUR}

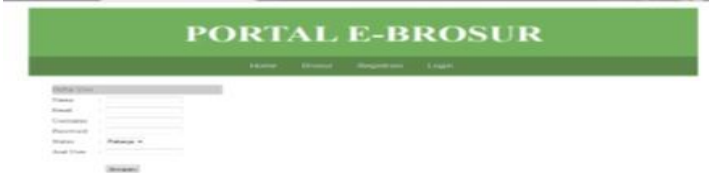

c. Form Pendaftaraan User

Form ini di gunakan untuk user mendaftar sebagar pengguna website.

Akan masuk ke dalam database ini.

c Database

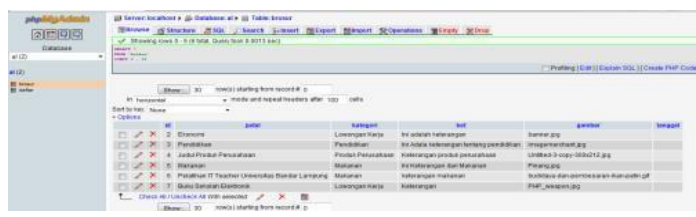

Gambar 4.5 Contoh database

d Form Login

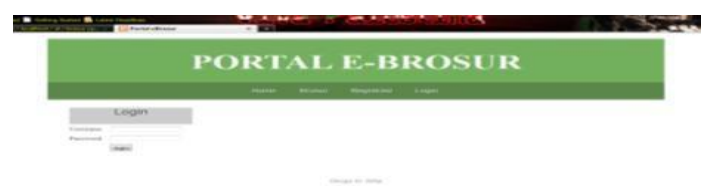

Gambar 4.6 Form login User

Form ini di gunakan untuk loginya user masuk ke dalam website

e From Upload

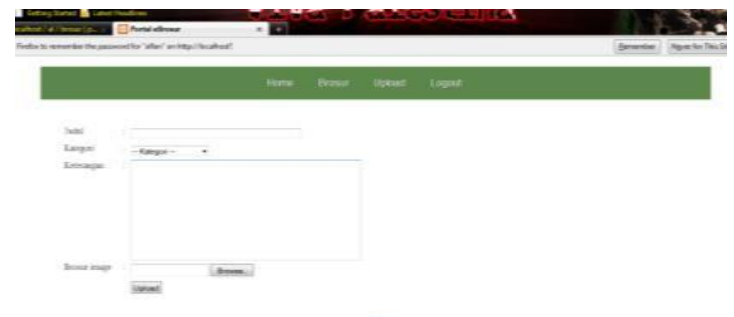

Gambar 4.7 
Form katagori

Setelah di upload akan masuk ke form tersimpan di form katagori

\section{f $\quad$ Form Katagori}

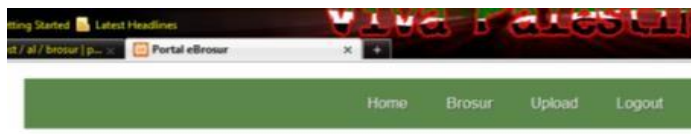

Brosur Berdasarkan Kategori

Lowongan Keria

Pendidikan

Makanan

Produk Perusahaan

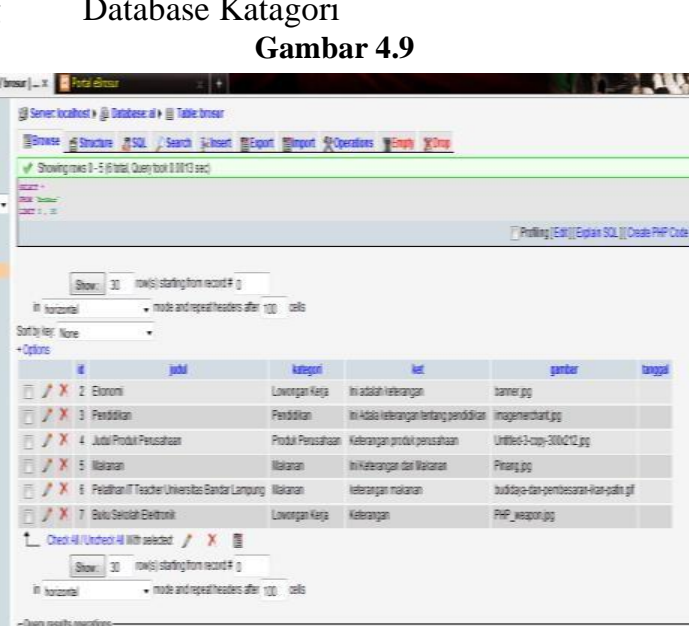

\subsection{Pengujian Aplikasi}

Aplikasi website yang telah dibuat, selanjutnya diuji melalui teknik pengujian perangkat lunak yang meliputi pengujian white box.

Dalam hal ini, pengujian tidak dilakukan terhadap keseluruhn program secara utuh, namun dilakukan sampel pengujian terhadap proses tertentu.

Pengujian White Box terhadap prosedur penguploadan file materi,tugas dan tugas dan materi, algoritma dari proses pengisian proyek baru adalah sebagai berikut :

1. Isi form login

2. Form menu kemudian pilih menu brosur.

3. Isi form upload brosur.

4. Klik tombol upload.
Dibawah adalah flowchart dan flowgraf aplikasi portal e-brosur

\section{Flowchart}

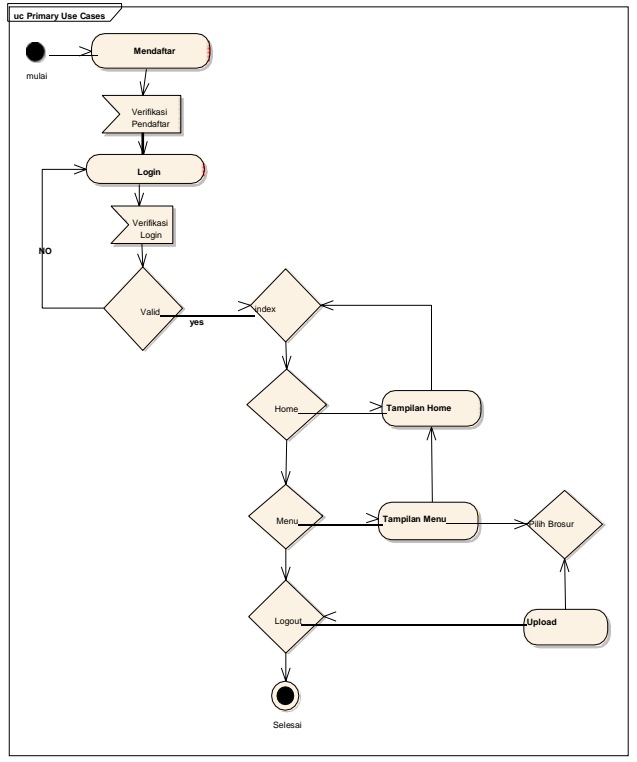

Gambar 4.6 Gambar flowchart 
2.

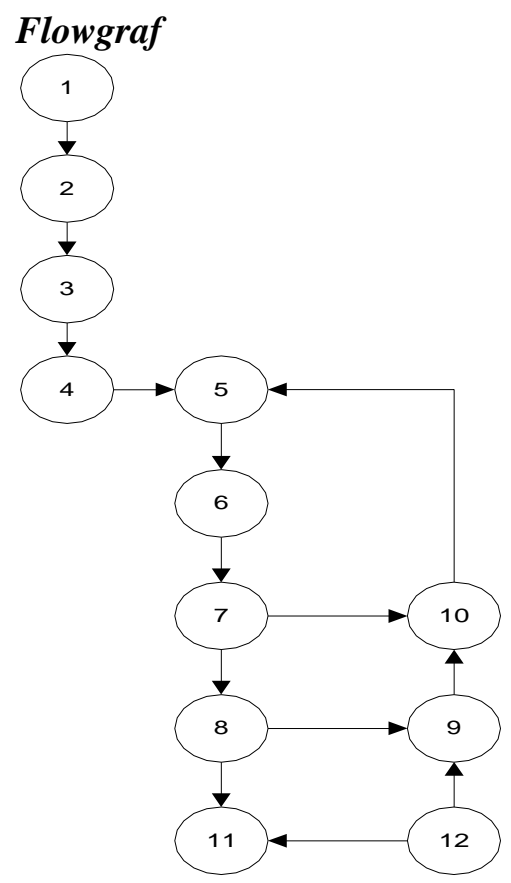

Basis set yang dihasilkan dari jalur independent secara linier adalah jalur sebagai

1. a-b-c-d-e-a-b-c-e

2. a-b-c-d-e-a-b-a-b-c-d-e-a

3. $a-b-c-d-e-a-b-a-b-c-d-e-a-b-c$

\section{Cyclomatic Complexcity}

Cyclomatic Complexcity V $(\mathrm{G})=\mathrm{E}=\mathrm{N}+2$

$$
\begin{aligned}
& \mathrm{E}=\mathrm{Jalur} / \text { Path } \\
& \mathrm{V}(\mathrm{G})=\mathrm{E}-\mathrm{N}+2 \\
& \mathrm{~V}(\mathrm{G})=13-12+2 \\
& \mathrm{~V}(\mathrm{G})=3
\end{aligned}
$$

a. Pengujian Aplikasi Pengujian Blcak Box

Pengujian selanjutnya dilakukan untuk memastikan bahwa suatu event atau masukan akan menjalankan proses yang tepat dan menghasilkan output sesuai dengan rancangan.

\begin{tabular}{|c|c|c|c|}
\hline Input & Proses & Output & $\begin{array}{l}\text { Hasil } \\
\text { Peng } \\
\text { ujian }\end{array}$ \\
\hline $\begin{array}{l}\text { Penekan } \\
\text { an } \\
\text { Tombol } \\
\text { Login }\end{array}$ & $\begin{array}{l}m- \\
\text { login.php }\end{array}$ & $\begin{array}{l}\text { Мепији } \\
\text { form тепи }\end{array}$ & $\begin{array}{l}\text { sesua } \\
i\end{array}$ \\
\hline $\begin{array}{l}\text { Penekan } \\
\text { an } \\
\text { tombol } \\
\text { register }\end{array}$ & $\begin{array}{l}m- \\
\text { Register.ph } \\
p\end{array}$ & $\begin{array}{l}\text { Menuju ke } \\
\text { form } \\
\text { register }\end{array}$ & $\begin{array}{l}\text { sesua } \\
i\end{array}$ \\
\hline $\begin{array}{l}\text { Penekan } \\
\text { an } \\
\text { tombol } \\
\text { upload }\end{array}$ & $\begin{array}{l}m- \\
\text { upload.php }\end{array}$ & $\begin{array}{l}\text { Masuk ke } \\
\text { database } \\
\text { lalu } \\
\text { menampilk } \\
\text { an kembali } \\
\text { form } \\
\text { upload } \\
\text { brosur }\end{array}$ & $\begin{array}{l}\text { sesua } \\
i\end{array}$ \\
\hline $\begin{array}{l}\text { Penekan } \\
\text { an } \\
\text { tombol } \\
\text { logout }\end{array}$ & $\begin{array}{l}m- \\
\text { logout.php }\end{array}$ & $\begin{array}{l}\text { Keluar } \\
\text { dari form }\end{array}$ & $\begin{array}{l}\text { sesua } \\
i\end{array}$ \\
\hline
\end{tabular}

\begin{tabular}{|c|l|l|l|l|l|l|l|}
\hline $\begin{array}{l}\mathrm{N} \\
\mathrm{o}\end{array}$ & Nama & & 2 & 3 & 4 & 5 & $\begin{array}{l}\text { Total } \\
\text { Poin }\end{array}$ \\
\hline 1 & Jefri & & 2 & 2 & 2 & 2 & 10 \\
\hline 2 & Rio Octora & & 2 & 2 & 2 & 2 & 10 \\
\hline 3 & $\begin{array}{l}\text { Raymond } \\
\text { Setiady }\end{array}$ & 2 & 2 & 2 & 2 & 10 \\
\hline 4 & Handry & & 2 & 2 & 2 & 2 & 11 \\
\hline 5 & Maikel & 2 & 2 & 2 & 2 & 10 \\
\hline
\end{tabular}

Untuk contoh pengujian terhadap beberapa perintah sebagai berikut :

Gambar 4.7 Gambar uji black box

\subsection{Implikasi Penelitian}

Penulis menyebarkan kuesioner perbandingan yang telah dibuat sebelumnya. Survey dilakukan dengan cara menyebarkan kuesioner ke pengguna internet dengan total keseluruhan 5 kuisoner. Tujuan dilakukan survey adalah untuk mengetahui perubahan yang terjadi setelah dilakukannya implementasi sistem. Penelitian dikatakan berhasil, apabila adanya perbandingan poin

di sebelum dan sesudah implentasi. (Pre-Test)

Hasil Pengamatan Sebelum Implementasi

Hasil nilai dari kuesioner yang diberikan pada pre-test adalah sebagai berikut:

\section{Gambar 4.8 Hasil pre-test}

a. Hasil Pengamatan Setelah Implementasi 
Setelah diimplementasikan sistem selanjutnya disebar kuisioner tahap kedua untuk mengukur dampak implementasi sistem, hasil nilai dari kuesioner yang diberikan adalah sebagai berikut:

\begin{tabular}{|c|l|l|l|l|l|l|l|}
\hline J & Nama & 1 & 2 & 3 & 4 & 5 & $\begin{array}{l}\text { Total } \\
\text { Poin }\end{array}$ \\
\hline 1 & Jefri & 2 & 2 & 2 & 2 & 3 & 11 \\
\hline 2 & $\begin{array}{l}\text { Rio } \\
\text { Octora }\end{array}$ & 2 & 2 & 2 & 2 & 3 & 11 \\
\hline 3 & $\begin{array}{l}\text { Raymond } \\
\text { Setiady }\end{array}$ & 2 & 2 & 2 & 2 & 2 & 10 \\
\hline 4 & Handry & 3 & 3 & 2 & 2 & 2 & 12 \\
\hline 5 & Maikel & 2 & 2 & 2 & 2 & 3 & 11 \\
\hline
\end{tabular}

Hasil post-test

Dari hasil perhitungan tersebut, maka t hitung akan dibandingkan dengan $\mathrm{t}$ tabel. Jika perbedaannya signifikan, maka disimpulkan bahwa hipotesa diterima. Untuk perhitungan ini, dapat disederhanakan dengan menggunakan fungsi dari Program Microsoft excel. Microsoft Excel merupakan perangkat lunak untuk mengolah data secara otomatis meliputi perhitungan dasar, penggunaan fungsifungsi, pembuatan grafik dan manajemen data. Dari data hasil pre test dan post test yang telah dilakukan sebelumnya, dapat diringkas menjadi tabel berikut ini.

Data tersebut adalah hasil rangkuman dari hasil kuesioner yang sudah dijelaskan pada bab sebelumnya. Dari data tersebut, lalu data digenerate menggunakan fungsi data analysis dari Microsoft excel 2007 dan akan menghasilkan tabel berikut:

\begin{tabular}{|c|c|c|c|c|c|}
\hline \multirow[b]{2}{*}{ NO } & \multirow[b]{2}{*}{ sebelum } & \multirow[b]{2}{*}{ sesudah } & \multicolumn{2}{|c|}{ t-Test: Paired Two Sample for Means } & \multirow[b]{2}{*}{ Variable 2 } \\
\hline & & & & Variable 1 & \\
\hline 1 & \begin{tabular}{|l|}
10 \\
\end{tabular} & 11 & Mean & 10.2 & 11 \\
\hline 2 & 10 & 11 & Variance & 0.2 & 0.5 \\
\hline 3 & 10 & 10 & Observations & 5 & 5 \\
\hline 4 & 11 & 12 & Pearson Correla & 0.790569415 & \\
\hline 5 & 10 & 11 & Hypothesized N & 0 & 0 \\
\hline & & & 을 & 4 & 4 \\
\hline & & & t Stat & -4 & 4 \\
\hline & & & $P(T<=t)$ one-tail & 0.008065045 & \\
\hline & & & t Critical one-tai & 2.131846782 & \\
\hline & & & $P(T<=t)$ two-tail & 0.01613009 & \\
\hline & & & tCritical two-tai & 2.776445105 & \\
\hline
\end{tabular}

Gambar 4.11

Hasil T-Test

Dari tabel T-Test dapat dianalisis sebagai beirkut a. Dari hasil analisis Paired samples statitics dapat dilihat bahwa variabel responden jumlah data $(\mathrm{N})$ sebanyak 5 dengan rata-rata 10,2 dan 11. Sedangkan standard deviasinya sebesar 0,17 (pre test) dan 0,72 (post test).

b. Dari hasil analisis korelasi yang digunakan untuk mengetahui hubungan antara dua variabel dan untuk mengetahui arah hubungan yang terjadi. Maka korelasi yang terjadi adalah 0,79 .

c. $\mathrm{T}$ hitung dari tabel di atas didapat nilai $\mathrm{t}$ hitung adalah -4

d. Tabel distribusi t dengan $a=5 \%$ adalah $2,5 \%$ dengan derajat

kebebasan (df) berdasarkan tabel di atas adalah 9. Dengan pengujian 2 sisi (signifikansi $=0,025$ ) hasil diperoleh untuk $t$ tabel sebesar 2,77 (lihat lampiran tabel t).

e. Nilai $-\mathrm{t}$ hitung $<-\mathrm{t}$ tabel $-4<-2,77$ dan $\mathrm{P}$ value $(0,000<0,05)$ maka Ho ditolak.

Oleh karena nilai -t hitung < - t tabel dan Pvalue < ),05 maka Ho ditolak, artinya bahwa ada perbedaan yang signikan antara sebelum dan setelah penerapan aplikasi website portal $e$ brosur.

Apabila tabel hasil pre test dan post test digambarkan menjadi grafik, maka akan tampak perbedaan hasil dari sebelum dan sesudah penerapan aplikasi website portal e-brosur

\begin{tabular}{|l|l|l|}
\hline NO & sebelum & sesudah \\
\hline 1 & 10 & 11 \\
\hline 2 & 10 & 11 \\
\hline 3 & 10 & 10 \\
\hline 4 & 11 & 12 \\
\hline 5 & 10 & 11 \\
\hline
\end{tabular}

berbasis modern advertising methods untuk efektivtas periklanan.

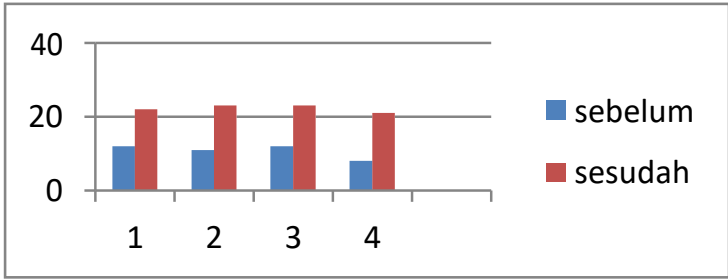

Gambar 4.12

Pre-Test dan Post-Test 
Dari grafik tersebut, terlihat bahwa terjadi perbedaan signifikan terhadap hampir keseluruhan pengguna e-brosur. Hal ini disebabkan karena pada user tersebut sebelum belum adanya yang menggunakan aplikasi website portal e-brosur berbasis modern advertising methods.

\subsection{Kesimpulan}

Dalam penelitian ini penulis menyimpulkaan hal sebagai berikut:

a. Dengan adanya portal e-brosur ini diharapkan para pembuat iklan dapat menggunakan portal e-brosur sebagai media promasinya sehingga bisa lebih mudah

b. Dengan adanya e-brosur pencari iklan dapaat dengan mudah mendapatkan iklan yang diinginkan.

c. Dengan adanya aplikasi portal e-brosur ini maka pencarian iklan menjadi efektif karna mudah untuk diakses oleh pengguna internet dan berdasarkan hasil kuisioner ternyata belum adanya yang menggunakan aplikasi website portal e-brosur berbasis modern advertising methods sebagai media promasi.

\subsection{Saran}

Penulis mengharapkan penelitian ini dapat dikembangkan lebih lanjut diantaranya:

1. Diharapkan Portal e- brosur ini dapat digunakan oleh seluruh pembuat iklan.

2. Dengan menggunakan portal e-brosur ini pencarian iklan dapat dengan mudah mencari iklan sesuai kebutuhannya.

3. Dengan mengunakan portal e-brosur dapat mengurangi pengguna brosur dengan mengunakan kertas.

\section{DAFTAR PUSTAKA}

1) (Zend Engine (http://www.zend.com)diakses 16februari-2013)

a. http://visualcase.com/tutorials/umltutorial.html) diakses tanggal 10februari-2012)

2) Bertha (2006): Staf Pengajar Fakultas Ekonomi Universitas Surabaya) dengan judul "Internet Marketing: Konsep Dan Persoalan Baru Dunia Pemasaran",

3) Ivan Bulut and bojana Radenkovic Sosic(2011) candidat Doktor Megatrend Universty, Belgrade: "kegiatan tanggung jawab sosial sebuah metode iklan modern?"

4) Warta (2008): "Korelasi antara kualitas portal detik portal dengan kepuasan member PT AMS".

5) Kotler P dan Keller (2007): Manajemen Pemasaran, edisi 12 Jilid 2, Pearson Prentice Hall, Indeks

6) Loka Dwiartara, 2002, "Buku PHP : Menyelam dan Menaklukan Samudra PHP”.

7) Kotler dan Gary Armstrong, (2008). Principles of Marketing : Pearson Prentice Hall, Pearson Education International.

8) F.Dzefkins, Oglasavanje, Clio, Beograd, 2003,p.10.)

9) Kamus besar bahasa Indonesia (2002 ): arti dari efektivitas (Hal 284).

10) Prof. DR. M. Suyanto Dalam Bukunya Electronic Market

11) Dokumen Kepuasan bidang Komunikasi Sosial tentang Etika dalam Iklan. L'Osservatore Romano, N. 16,16 April 1997, hlm. II.

12) Kotler, Philip. 1997. Marketing Management : Analysis, Planning, Implementation, and Control. 9 th ed. New Jersey : Prentice - Hall.

13) Thomas M. Garrett, SJ., 1961: 37-94. Nomor 1-7, lihat Thomas M. Garrett, SJ., 1961:p 38; p8, lihat Thomas M. Garrett, SJ., 1961: 46-51.

14) Bdk .Niklos Tomko, "Eastern Europe: The Media in Transition", dalam Concillium, SCM Press, London, 1993/6. Hlm. 47-49.

15) Thomas M. Garrett, SJ., 1961: 4042,44-45, 74-77,41. 